Review Article

\title{
A Review of Precast Concrete Beam-to-Column Connections Subjected to Severe Fire Conditions
}

\author{
Noor Azim Mohd Radzi (D), Roszilah Hamid (D), Azrul A. Mutalib (D), \\ and A. B. M. Amrul Kaish \\ Department of Civil Engineering, Faculty of Engineering and Built Environment, Universiti Kebangsaan Malaysia, UKM, \\ Bangi 43600, Selangor D. E, Malaysia \\ Correspondence should be addressed to Roszilah Hamid; roszilah@ukm.edu.my
}

Received 27 May 2020; Revised 10 November 2020; Accepted 16 November 2020; Published 30 November 2020

Academic Editor: Chiara Bedon

Copyright (c) 2020 Noor Azim Mohd Radzi et al. This is an open access article distributed under the Creative Commons Attribution License, which permits unrestricted use, distribution, and reproduction in any medium, provided the original work is properly cited.

Fire exposure can have a significant impact on the structural integrity and robustness of precast concrete beam-to-column connections. Given the importance of fire safety in the design of a structure, it is critical to understand the damage that may occur in the event of a fire to be able to prevent the building from collapsing. No comprehensive study has been carried out to determine the effects of fire on semirigid and pinned concrete beam-to-column connections. Most studies focused on the impact of exposure of rigid concrete beam-to-column connections to high temperatures. This paper is a comprehensive review of the literature on the performance of precast concrete beam-to-column connections under fire conditions. The key areas in this review are the momentrotation-temperature characteristics and fire effect on precast concrete beam-to-column connections. This paper focuses primarily on the case studies of real fires, large-scale fire tests, computer simulations and analytical models, fire resistance tests on the connection elements, and assessment and rehabilitation of fire-damaged precast concrete. The paper also discusses the current issues and possible challenges.

\section{Introduction}

The precast concrete frame structure developed by the construction industry has resulted in high production efficiency, better product quality, and low labour intensity [1-6]. The mechanisation and standardisation of prefabrication methods have made the production of concrete elements sustainable [7-9]. Connections are critical in ensuring structural integrity, adequate strength, energy dissipation, stiffness, and ductility of the designed precast concrete structures $[1,7,10,11]$. Connections must fulfil various design and performance criteria, including flexibility in resisting the ultimate design force, production efficiency, and good in-service structural behaviour of the components and satisfy the requirements for fire safety and durability and aesthetically pleasing $[1,12,13]$.

Depending on their stiffness, precast concrete beam-tocolumn connections are classified as pinned or rigid connections. Connections with low stiffness are classified as pinned connections, and those with high stiffness are fixed connections. However, precast concrete beam-to-column connections are often not fully rigid or perfectly pinned because they exhibit semirigid behaviour $[14,15]$. These connections have an intermediate stiffness between fully rigid and perfectly pinned and can partially transmit stress $[14,16]$. Even though they have finite stiffness and moment resistance, these connections are usually weaker than the connected elements [17]. Semirigid connections give more realistic and reliable results and are more economical [18].

The failure of connections during natural and humanmade disasters has an adverse impact on precast structures. Precast concrete structures have a relatively low integrity and are more vulnerable to progressive collapse than the traditional cast-in-place concrete structures [9]. The design of precast structures must take into account the occurrence of a fire as it is one of the accidental actions [11, 19]. Structural fire design is critical in ensuring the general fire safety of buildings [20]. Exposure to fire could considerably 
reduce the strength and stiffness of a building [21]. Severe fires in large buildings are rare and unpredictable incidents but can cause catastrophic loss of life and property damage and affect the structural integrity and robustness of buildings $[20,22]$. The construction of safer buildings can reduce the risks of loss of life and property in the event of fire [20].

There are reports of actual fire incidents involving precast buildings [23-26]. The postfire condition of these buildings indicates that the structures sustained serious damage because of the failure of the beam-column connections and collapsed. However, the reasons for the failure of the precast beam-to-column connections exposed to high temperatures are not known. The research that compared three different methods of precast concrete beam-to-column connections (dry, semidry, and wet) at elevated temperatures [3] was not able to determine the mechanical properties of the connections postfire. Most research focused on rigid connections under moment-resisting frame systems, particularly the top reinforcement continuity in a ductile connection at the support [22, 23, 27-29].

Besides the established impacts of fire on reinforced concrete, such as explosive spalling, cracking, reduced compressive strength of the concrete $\left(f_{\text {cu }}\right)$, and reduced yield strength of the reinforcement $\left(f_{\mathrm{y}}\right)$ [30-32], the postfire moment-rotation $(M-\theta)$ characteristics of semirigid connections are not yet understood. During a fire, the moment capacity $(M)$, rotational capacity $(\theta)$, and rotational stiffness $(S)$ of semirigid connections are adversely affected by the change in modulus of elasticity $(E)$ and moment of inertia $(I)$ [33]. The changes are caused by the lower strength of the materials and the cross section of the structure. Also, the moment-rotation characteristics are affected by the postfire effect on the connection elements in precast structures, such as bearing pad, grout, bolts, and welds.

Connections must be protected with concrete or grout and enclosed in or sprayed with fire-resistant materials because fire exposure could weaken precast concrete beamto-column connections. Connections must be given the same protection as the components and frame of a structure. Structural engineers are responsible for ensuring the structural safety of the precast component connection as well as the compliance of the joint functional requirements, such as fire safety and thermal insulation [4].

There are many questions concerning the exposure of precast buildings to fire. Some of the questions are the semirigid behaviour of precast concrete beam-to-column connections under severe fire conditions, the capability of connections under increased rotation and reduced moment capacity, the effect of fire-damaged reinforced concrete on the strength and stiffness of the semirigid connections, and the moment-rotation-temperature characteristics at elevated temperatures.

This article presents a comprehensive review of the behaviour of precast concrete beam-to-column connections under fire conditions. It will also discuss connection performance in terms of the moment-rotation-temperature characteristics and the effect of fire on precast concrete beam-to-column connections. The primary focus of this article is the case studies of real fires, large-scale fire tests, computer simulations and analytical models, fire resistance tests on connection elements, and assessment and rehabilitation of fire-damaged precast concrete. Finally, this paper explores the critical issues and challenges faced by the construction industry and gives recommendations for future research.

\section{Moment-Rotation-Temperature Characteristics of Precast Concrete Beam- to-Column Connections}

The connection of a precast concrete beam-to-column connection is semirigid because of its rotational behaviour at the joint. The connection rotates when a moment is induced through the application on a load. The rotational characteristics of the connections are a moment-rotation relationship. The moment-rotation-temperature relationship of a connection is established when the connection is exposed to fire. In general, the full moment-rotation-temperature connections in a fire consist of a moment-rotation at ambient temperature and a rotation-temperature at high temperatures [34]. The critical properties of a precast concrete beam-to-column connection are dependent on the moment-rotation characteristics of the connection, including the beam end moment capacity, rotational stiffness, rigidity, and fixity factor $(\gamma)[12]$.

2.1. Classification of Semirigid Connection. There are two effective methods for classifying semirigid connections $[11,14]$. Figure 1 [11] shows the beam-line method. The moment-rotation shown in Plot 1 is for a rigid connection with complete rotational continuity, while Plot 2 shows a pinned connection with no moment resistance. The semirigid connections in Plots 3, 4, and 5 tend to exhibit the behaviour of a connection in a precast concrete structure, depending on the type of connection. The beam's moment of resistance $\left(M_{\mathrm{R}}\right)$ and relative pin-beam end rotation $\left(\theta_{\mathrm{R}}\right)$ at the support is given by

$$
\begin{aligned}
M_{R} & =\frac{w L^{2}}{12}(\mathrm{kNm}), \\
\theta_{R} & =\frac{w L^{3}}{24 E I}(\mathrm{rad}),
\end{aligned}
$$

where $w$ is uniform distribution load $(\mathrm{kN} / \mathrm{m}), L$ is the span length of the beam $(\mathrm{m}), E$ is the modulus of elasticity of the concrete $=(\sigma / \varepsilon)=((F / A) /(\Delta L / L))\left(\mathrm{MPa}\right.$ or N/mm $\left.{ }^{2}\right)$, and $I$ is the moment of inertia for a rectangle concrete beam $=$ $\left(b h^{3} / 12\right)\left(\mathrm{mm}^{4}\right)$.

However, the simplified moment-rotation relationship in Figure 2 was developed for practical applications and to obtain reliable results [14]. $M_{\mathrm{y}, \mathrm{lim}}$ is the yielding moment, and $M_{\mathrm{u}}$ is the flexural strength moment of the connection. Secant rotational stiffness $\left(R_{\mathrm{sec}}\right)$ is used in a linear analysis that considers the nonlinearity response of the connection in the moment-rotation curve. Secant rotational stiffness is a safe approximation for representing the behaviour of connections in a global analysis of structural stability. 


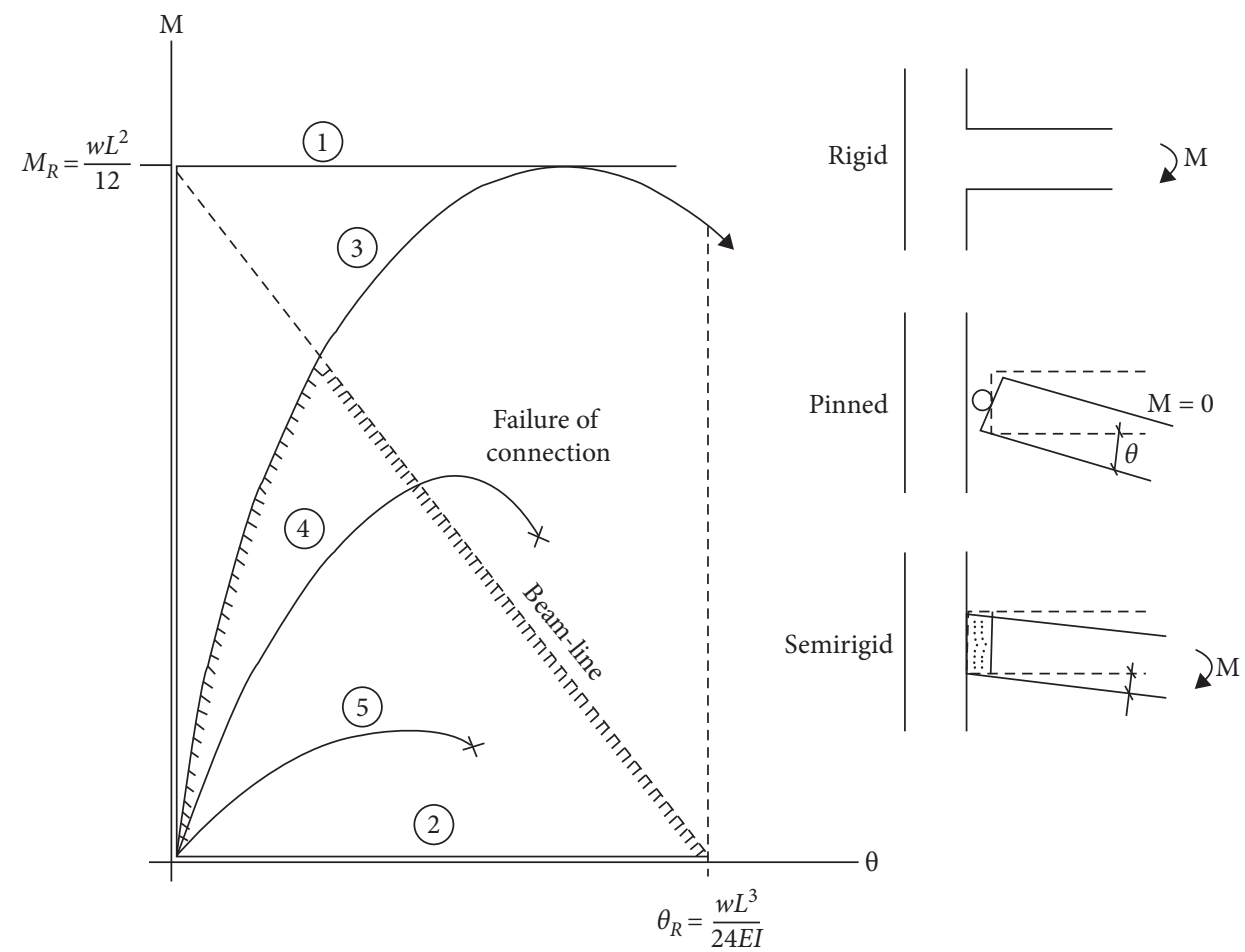

FIgURE 1: Moment-rotation relationship beam-line method [11].

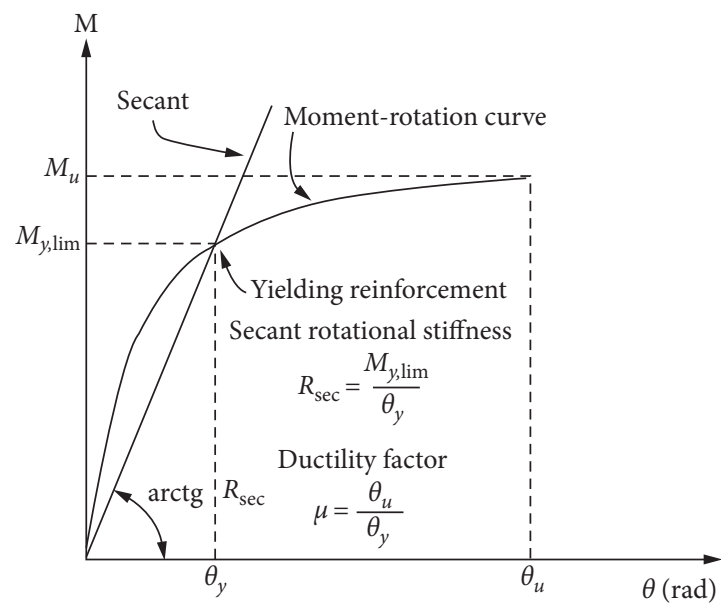

FIgURE 2: Simplified moment-rotation relationship [14].

The second method for classifying semirigid connections uses the connection classification system shown in Figure 3 [11]. This system consists of five distinct zones. Zone I and V represents pinned connections and rigid connections, respectively. Zone II represents semirigid connections with low strength $(0.14<\gamma \leq 0.40)$, Zone III represents semirigid connections with moderate strength $(0.40<\gamma \leq 0.67)$, and Zone IV represents semirigid connections with high strength $(0.67<\gamma \leq 0.90)$. The equation for Monforton's fixity factor [13] is given by

$$
\gamma=\left(1+\frac{3 E I}{S_{E} L}\right)^{-1},
$$

where $L$ is the span length of the beam (m), $E$ is the modulus of elasticity for concrete $=(\sigma / \varepsilon)=((F / A) /(\Delta L / L))(\mathrm{MPa}$ or $\left.\mathrm{N} / \mathrm{mm}^{2}\right), I$ is the moment of inertia for rectangle concrete beam $=\left(b h^{3} / 12\right)\left(\mathrm{mm}^{4}\right)$, and $S_{\mathrm{E}}$ is the rotational stiffness $(\mathrm{kNm} / \mathrm{rad})$.

Equations (2) and (3) clearly show that the modulus of elasticity and moment of inertia of a structure are critical in 


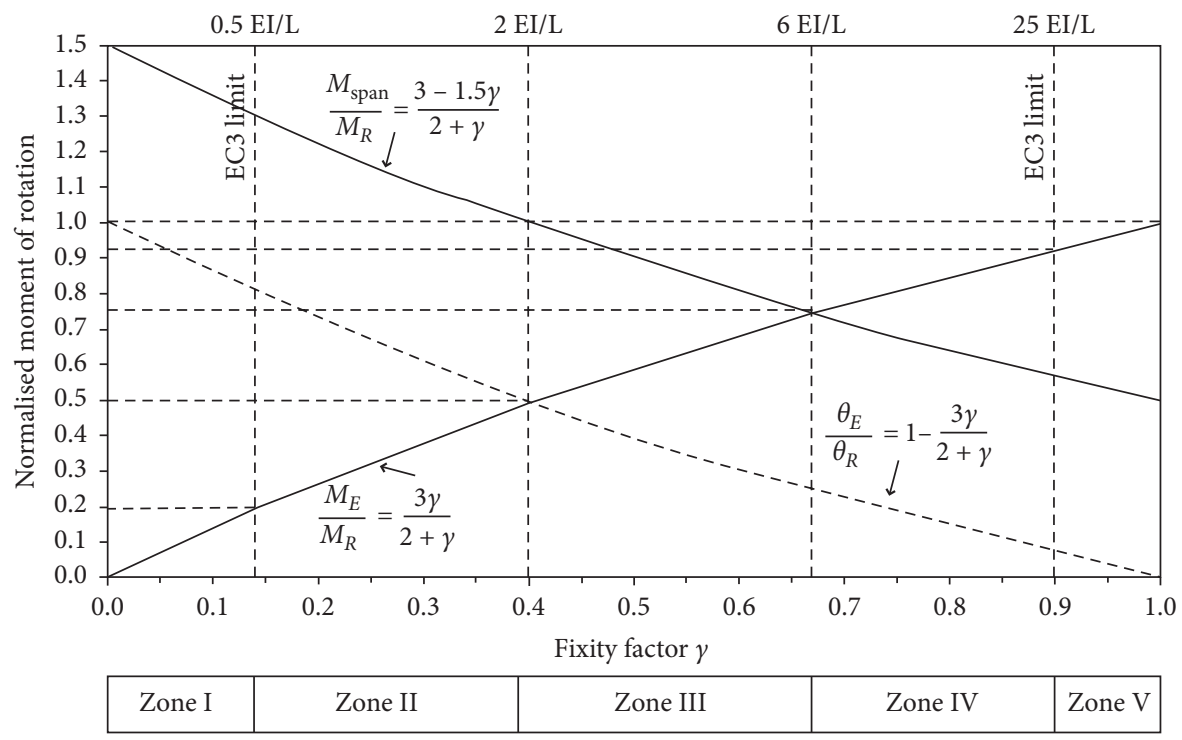

Figure 3: Connection classification system [11].

the classification of beam-to-column connection. Any change that reduces the strength of the materials and cross section of structures affects the moment capacity, rotational capacity, rotational stiffness, and fixity factor of semirigid connections.

2.2. The Moment-Rotation-Temperature Relationship of Semirigid Connection. Refs. [34-37] described the momentrotation-temperature relationships for beam-to-column connections. Most of the studies focused on steel structures. However, the fundamental relationship is also applicable to concrete structures. Observations of fire-damaged structures and fire tests showed that simple connections could resist significant moment even at large deformations. The following modified Ramberg-Osgood equation [35] was used to represent the moment-rotation-temperature data obtained from experimental fire tests:

$$
\begin{aligned}
& \varnothing=\frac{M}{A}+0.01\left(\frac{M}{B}\right)^{n}-\text { for a one }- \text { stage moment }- \text { rotation curve, } \\
& \varnothing=\varnothing_{1}+\frac{\left(M-M_{1}\right)}{A_{1}}+0.01\left[\frac{\left(M-M_{1}\right)}{B_{1}}\right]^{n 1}-\text { for a two }- \text { stage moment }- \text { rotation curve, }
\end{aligned}
$$

where $\varnothing$ is the joint rotation ( $\mathrm{rad}), \varnothing_{1}$ is the rotation at which the beam flange comes into contact with the column $(\mathrm{rad}), M$ is the moment capacity $(\mathrm{kNm}), M_{1}$ is the moment capacity corresponding to $\varnothing_{1}, A$ and $A_{1}$ are the stiffness of the joints, $B$ and $B_{1}$ are the strength of the joints, and $n$ and $n_{1}$ are the sharpness of the curve.

Figure 4 shows the moment-rotation-temperature curves for both stages of moment-rotation behaviour [35, 36]. The figure shows reduced moment-rotation curves with increasing temperatures. The parameters representing the joint's stiffness and strength showed similar characteristics in that the values for both parameters decrease with rising temperatures following the strength reduction factors of structural steel presented in the design codes. Further test by Rahnavard and Thomas [37] on various types of steel connection (bolted endplate, bolted cover plate, bolted tee, and welded cover plate) showed a change in the behaviour of the moment capacity as well as stiffness as the temperature increased from 20 to $300^{\circ} \mathrm{C}$.
The moment-rotation-temperature relationships for a concrete structure are influenced by the fire effects on the reinforced concrete structure, including deflection, cracking, spalling, loss of stiffness and strength, and loss of reinforcement strength. Figure 5 shows the types of fire damage observed in semirigid conditions. The change in the properties of a concrete structure as a result of exposure to high temperatures affects the moment capacity, rotational capacity, rotational stiffness, and fixity factor of semirigid connections.

Spalling is the breakaway of a layer of concrete from the surface as a result of the high internal steam pressure from water vaporisation $[30,38,39]$. Spalling can be categorised as aggregate spalling, explosive spalling, surface spalling, and corner/sloughing-off spalling, as shown in S1, S2, and S3. Explosive spalling is the most severe form of spalling and is characterised by the burst-out of concrete pieces that are accompanied by a sudden release of energy and loud sounds 


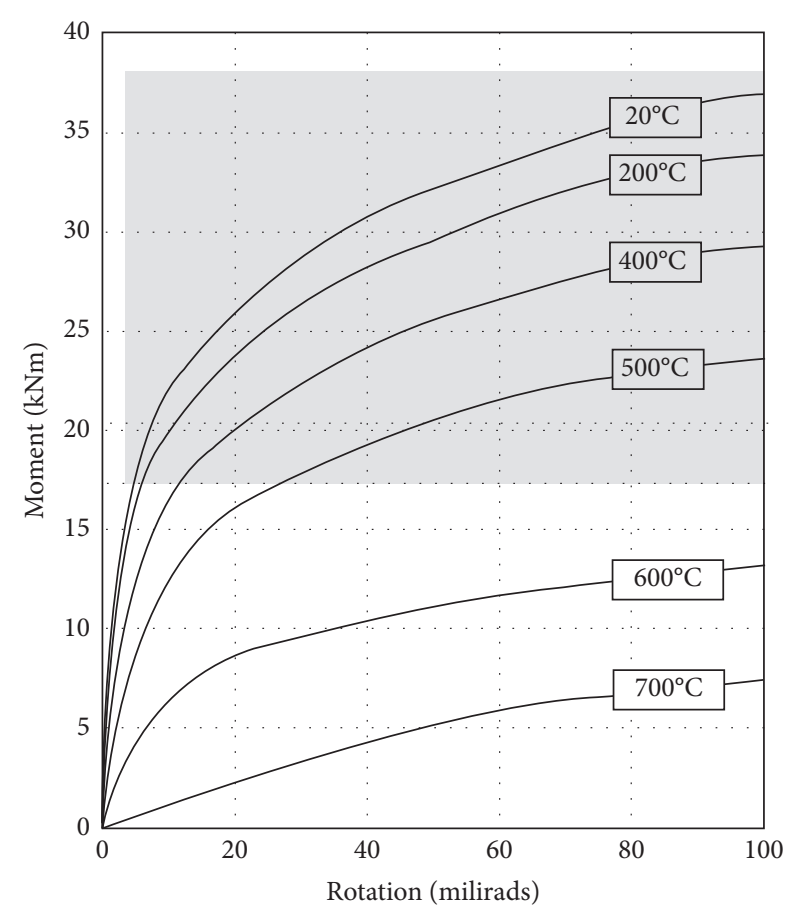

Extrapolation

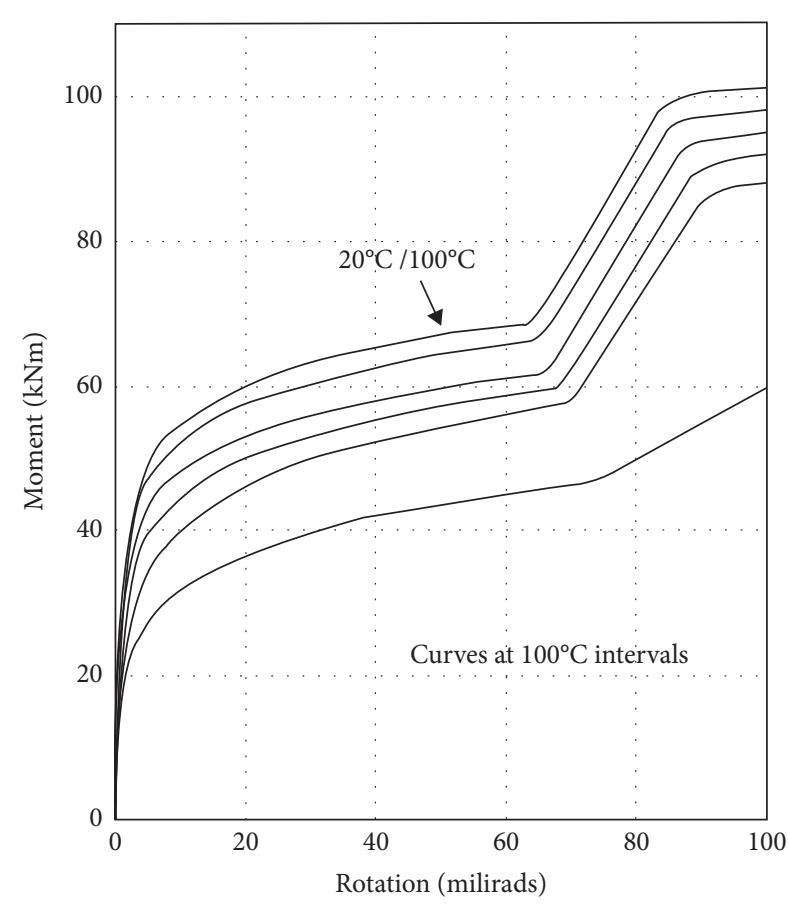

(b)

Figure 4: Moment-rotation-temperature curves: (a) one-stage and (b) two-stage [35, 36].

[40]. In a standard building fire, spalling starts at a temperature of between 250 and $420^{\circ} \mathrm{C}$, depending on the heating rate and concrete properties [41]. Prefabricated concrete structures constructed using high-strength concrete (HSC) have a higher risk of severe explosive spalling. Despite the high strength and excellent durability of this concrete, its low permeability proves to be a disadvantage at high temperatures.

The structural performance of reinforced concrete structures is influenced primarily by spalling, which causes loss of material, smaller cross-sectional areas $(\Delta \mathrm{d})$, and exposure of the reinforcing steel to excessive temperatures, as shown in Section 1-1 [30, 38, 39, 41]. Researchers have elucidated the critical role of spalling in reducing the fire resistance of a structure [42, 43]. The adverse effect on fire resistance occurs at the beginning of the spalling process, where the dismantlement of large pieces of concrete from the surface exposed to fire reduces the thickness of concrete cover and cross-sectional area and thus exposes the reinforcements to fire. However, the impact on fire resistance is less severe in the late stages of a fire, when the spalling generally causes the breaking up of thin layers of concrete and minor dislodgement of the surface. Minor gradual reduction of the surface layer may continue after the fire has stopped burning.

The thermal conductivity of concrete is dependent on the type of aggregates used in the concrete. The use of cathode ray tube (CRT) waste as aggregates in the production of concrete produces concrete with excellent fire resistance at temperatures of up to $600^{\circ} \mathrm{C}$ [44]. Nanosilica is a material with advanced pozzolanic properties and can act as a microfiller in cement. It can also enhance the hydration of concrete material by increasing its pozzolanic activity [45]. Innovative fireproof concrete containing high volumes of fly ash with colloidal nanosilica (HVFANS) can be used as passive fire protection in high-risk structures $[45,46]$. The high-strength mortar produced through the incorporation of a high amount of fly ash and colloidal nanosilica and exposure to a temperature of $700^{\circ} \mathrm{C}$ has a comparable residual strength as the control cement mortar specimens before its exposure to high temperatures [47-49].

During a fire, concrete experiences a permanent loss of stiffness and strength, which is known as thermal damage and thermal decohesion, respectively [40]. The chemical composition and physical structure of a concrete change considerably as a result of dehydration and high-temperature response [40]. Georgali and Tsakiridis [38] demonstrated the general condition of concrete that have been exposed to varying temperatures, as shown in Figure 6. The colour of the concrete remained unchanged when exposed to a temperature of up to $300^{\circ} \mathrm{C}$. The colour of the concrete changes from grey to pink as the temperature increases. The colour changed from pink to red when the temperature is between 300 and $600^{\circ} \mathrm{C}$, to whitish-grey at 600 to $900^{\circ} \mathrm{C}$, and whitish-grey to buff at 900 to $1000^{\circ} \mathrm{C}$. The pink discolouration is due to the presence of an iron compound in the fine or coarse aggregates.

The deterioration of mechanical properties in terms of the yield strength and modulus of elasticity of steel reinforcements during a fire is a critical factor affecting the 


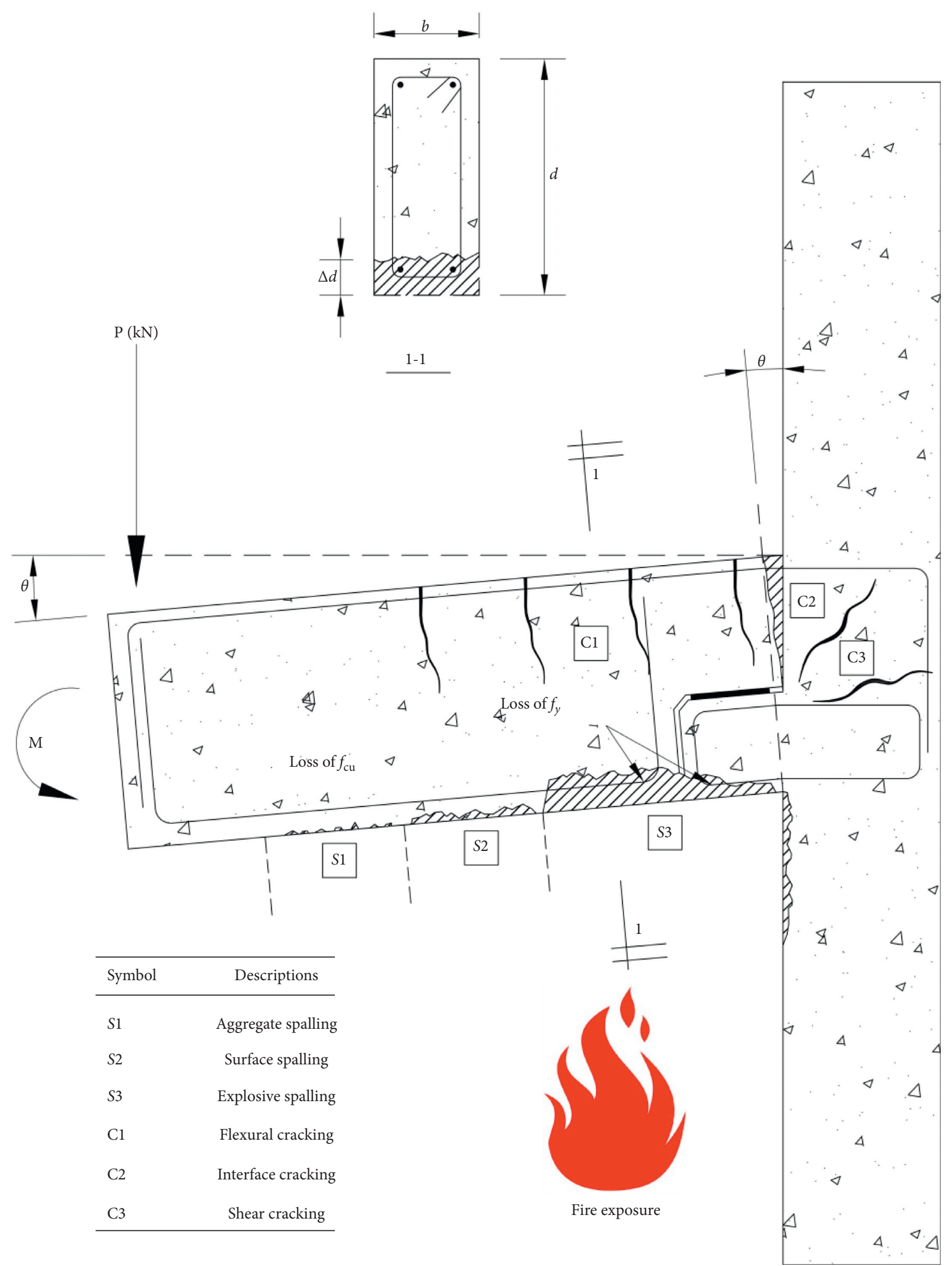

FIGURE 5: Different forms of fire damage observed in semirigid conditions (concrete nib). 


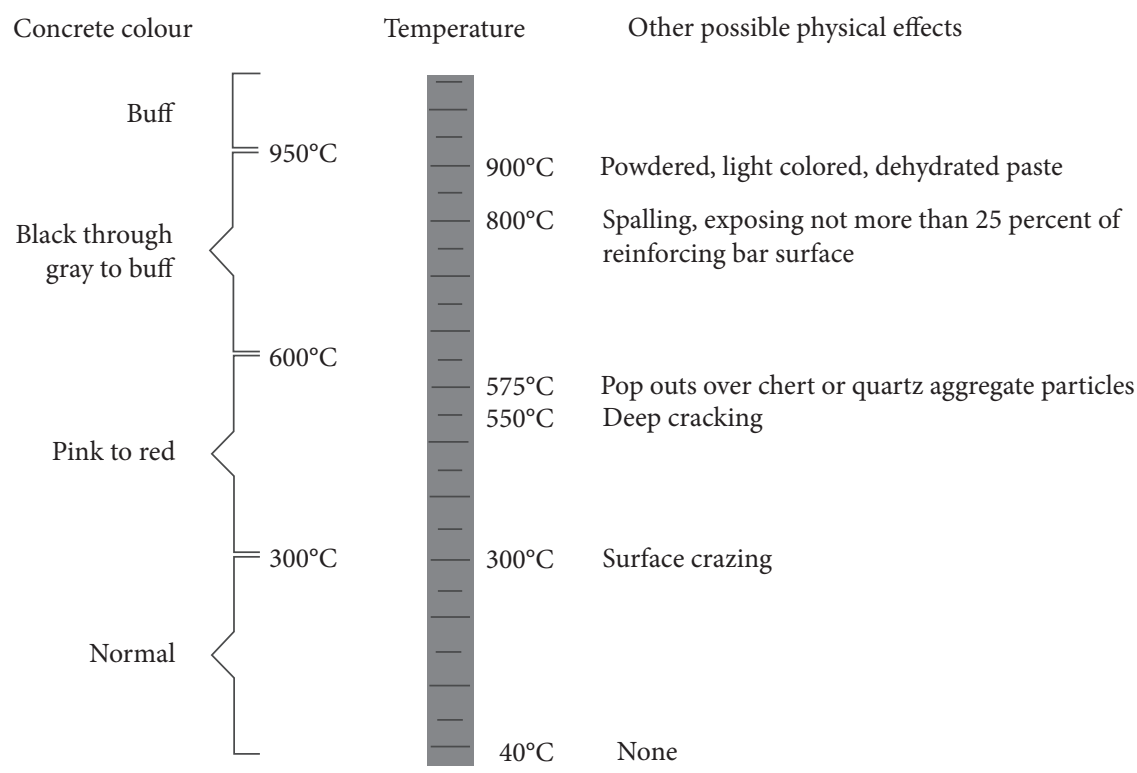

FIgURE 6: Visual evidence of the temperature to which concrete has been heated [38].

performance of concrete structures. The concrete cracking (flexural, interface, and shear), as shown in $\mathrm{C} 1, \mathrm{C} 2$, and $\mathrm{C} 3$, and concrete spalling during a fire exposes the steel reinforcement to high temperatures. The close distance of the concrete surface to the steel reinforcement may cause damage or collapse of the concrete structure during a fire. Steel reinforcements must be protected from exposure to a temperature greater than 250 to $300^{\circ} \mathrm{C}$, depending on the type of reinforcement [20], since steel with low carbon content exhibits "blue brittleness" at temperatures between 200 and $300^{\circ} \mathrm{C}[50]$. A review of the literature $[3,23,51,52]$ revealed that steel reinforcements begin to lose yield and ultimate strength at $200^{\circ} \mathrm{C}$ and $300^{\circ} \mathrm{C}$, respectively. Exposure to temperatures higher than $400^{\circ} \mathrm{C}$ could cause a considerable expansion of the reinforcements. Exposure to higher temperatures of up to $700^{\circ} \mathrm{C}$ results in a $20 \%$ reduction of load-bearing capacity. At temperatures higher than $800^{\circ} \mathrm{C}$, the tensile strength of the reinforcements is significantly lower.

The combination of the above fire damages causes a marked deterioration of the beam-to-column connection. Further exposure to high temperature weakens both the concrete and the reinforcement. The tension reinforcement tends to slip due to the cracking of top joints. The values of modulus of elasticity and moment of inertia are markedly reduced. The continuous deflection at the midspan of the beam caused a larger rotation, which reduces the moment capacity of the joint. The reduced moment-rotation curve results in lower rotational stiffness and lower fixity factor. As a consequence, the beamto-column connection tended to collapse and overturn and failed despondently.

\section{The Effect of Fire on Precast Concrete Beam- to-Column Connections}

Beam-to-column connections are essential part of precast skeletal frames. Exposure of beam-to-column connections to extreme fires produces a destructive force that can cause structural deterioration. Tables $1-5$ present the findings of investigations on the behaviour of concrete beam-to-column connection exposed to high temperatures. The case studies comprise a real fire, large-scale fire tests, computer simulations, analytical models, fire resistance tests on the connection elements, and assessment and rehabilitation of fire-damaged precast concrete. This section will provide greater insight into the effects of fire on precast concrete beam-to-column connections in terms of descriptions, methods, parameters, and limitations.

3.1. Case Studies of a Real Fire. Table 1 lists the case studies of real fires of precast structures, namely, a plant in Turkey [23], a factory in Poland [25], and a production hall in Serbia [26]. Even though there are many case studies focused on real fire events, there is no report on the precast structures. Most of the studies focused on conventional structures that have rigid connections.

3.1.1. Cotton Thread Plant, Kahramanmaras, Turkey [23]. The plant was constructed in 1997 using $450 \mathrm{~mm} \times 450 \mathrm{~mm}$ precast concrete columns and $350 \mathrm{~mm} \times 1270 \mathrm{~mm}$ L-shaped precast concrete girders. The precast concrete columns were connected with the precast concrete girders using visible corbels, as shown in Figure 7. The information on the 
TABle 1: Case studies on real fires.

\begin{tabular}{|c|c|c|c|c|c|}
\hline $\begin{array}{l}\text { Author, year, } \\
\text { and ref. no. }\end{array}$ & Descriptions & Methods & Parameters & Limitations & Conclusions \\
\hline $\begin{array}{l}\text { Kose et al. } \\
(2006) \text { [23] }\end{array}$ & $\begin{array}{l}\text { Cotton thread plant, } \\
\text { Kahramanmaras, Turkey } \\
\text { (2003), containing precast } \\
\text { concrete column and girder }\end{array}$ & $\begin{array}{l}\text { (i) Visual } \\
\text { examination and } \\
\text { observation } \\
\text { (ii) Tensile test on } \\
\text { reinforcement } \\
\text { (iii) Ultrasonic } \\
\text { test and concrete } \\
\text { coring } \\
\text { (iv) Scanning } \\
\text { electron } \\
\text { microscope }\end{array}$ & $\begin{array}{l}\text { (i) Concrete } \\
\text { spalling } \\
\text { (ii) Aggregate } \\
\text { colour } \\
\text { (iii) CaO layer } \\
\text { (iv) } \\
\text { Reinforcement } \\
\text { tensile strength } \\
\text { (v) Concrete } \\
\text { compressive } \\
\text { strength } \\
\text { (vi) Concrete } \\
\text { cracking }\end{array}$ & $\begin{array}{l}\text { (i) Thermal behaviour } \\
\text { of the beam-to- } \\
\text { column connection at } \\
\text { high temperature } \\
\text { (ii) Level of } \\
\text { temperature during } \\
\text { the fire } \\
\text { (iii) Compressive } \\
\text { strength of heavily } \\
\text { damaged concrete } \\
\text { (iv) Rehabilitation } \\
\text { solution }\end{array}$ & $\begin{array}{l}\text { (i) Corbel was used to } \\
\text { connect the column to the } \\
\text { precast concrete girder } \\
\text { (ii) Several beam-to- } \\
\text { column connections have } \\
\text { failed } \\
\text { (iii) Due to concrete } \\
\text { spalling at high } \\
\text { temperature, steel } \\
\text { reinforcement lost their } \\
\text { strength leads to the } \\
\text { collapse of the girder }\end{array}$ \\
\hline $\begin{array}{l}\text { Wróblewski } \\
\text { et al. (2016) } \\
{[25]}\end{array}$ & $\begin{array}{l}\text { Personal care product } \\
\text { factory, Poland (2012), } \\
\text { containing precast column } \\
\text { and precast posttensioned } \\
\text { girder }\end{array}$ & $\begin{array}{l}\text { (i) Visual } \\
\text { examination and } \\
\text { observation } \\
\text { (ii) Tensile test on } \\
\text { prestressing } \\
\text { reinforcement } \\
\text { (iii) Scanning } \\
\text { electron } \\
\text { microscope }\end{array}$ & $\begin{array}{l}\text { (i) Column } \\
\text { verticality } \\
\text { (ii) Girder } \\
\text { deflection } \\
\text { (iii) Concrete } \\
\text { cracking } \\
\text { (iv) } \\
\text { Reinforcement } \\
\text { corrosion } \\
\text { (v) Prestressing } \\
\text { reinforcement } \\
\text { strength } \\
\text { (vi) Concrete } \\
\text { spalling } \\
\text { (vii) Concrete } \\
\text { microstructure }\end{array}$ & $\begin{array}{l}\text { (i) Thermal behaviour } \\
\text { of the beam-to- } \\
\text { column connection at } \\
\text { high temperature } \\
\text { (ii) Rehabilitation } \\
\text { solution }\end{array}$ & $\begin{array}{l}\text { (i) Corbel was used to } \\
\text { connect the column to the } \\
\text { precast concrete girder } \\
\text { (ii) Column inclined and } \\
\text { curved due to thermal } \\
\text { elongation of the roof } \\
\text { girder } \\
\text { (iii) Several beam-to- } \\
\text { column connections have } \\
\text { totally failed } \\
\text { (iv) High temperature } \\
\text { reduced prestressing force } \\
\text { and increased the } \\
\text { deflection of the girder }\end{array}$ \\
\hline $\begin{array}{l}\text { Radonjanin } \\
\text { et al. (2016) } \\
{[26]}\end{array}$ & $\begin{array}{l}\text { Production hall building, } \\
\text { Novi Sad, Serbia (2013), } \\
\text { containing precast concrete } \\
\text { column and precast beam }\end{array}$ & $\begin{array}{l}\text { (i) Visual } \\
\text { inspection on } \\
\text { physical effects } \\
\text { (ii) Dimension } \\
\text { measurement } \\
\text { (iii) Concrete } \\
\text { coring } \\
\text { (iv) Tensile test } \\
\text { on reinforcement } \\
\text { (v) Geodetic } \\
\text { survey }\end{array}$ & $\begin{array}{l}\text { (i) Column } \\
\text { verticality } \\
\text { (ii) Concrete } \\
\text { spalling } \\
\text { (iii) Aggregate } \\
\text { colour } \\
\text { (iv) Concrete } \\
\text { cracking } \\
\text { (v) Concrete } \\
\text { compressive } \\
\text { strength } \\
\text { (vi) } \\
\text { Reinforcement } \\
\text { tensile strength }\end{array}$ & $\begin{array}{l}\text { (i) Construction } \\
\text { method of beam-to- } \\
\text { column connection } \\
\text { (ii) Temperature and } \\
\text { duration of the fire }\end{array}$ & $\begin{array}{l}\text { (i) Beam-to-column } \\
\text { connection exhibited a } \\
\text { crumbling of concrete } \\
\text { (ii) Precast beam member } \\
\text { was rotated and tend to } \\
\text { decline } \\
\text { (iii) Two possible } \\
\text { rehabilitation solutions } \\
\text { include removal the } \\
\text { damaged surface and } \\
\text { retrofit }\end{array}$ \\
\hline
\end{tabular}

method used to connect the two components is not available. The concrete is a mixture of riverbed aggregates and Portland cement having a compressive strength of $25 \mathrm{MPa}$. All precast structural members have a $15 \mathrm{~mm}$ concrete cover. All precast concrete structural members do not have fire protection. The colour of the deformed concrete samples indicates that the fire burned for more than two hours, and the temperature is estimated to be around 800 to $900^{\circ} \mathrm{C}$.

The methods used in the case study include visual examination and observation, tensile test on the reinforcement, ultrasonic pulse velocity test, concrete coring, and scanning electron microscope (SEM). The damage sustained by the internal column was more severe than that experienced by the external column because of the internal walls between the two columns. The spalling of the concrete cover exposed the transverse reinforcements. The colour of the aggregates changed to pink or red. The yield and rupture strength of the steel reinforcement were lower than the values stated in the standard. The matrix of the concrete and the binding between the concrete and steel was destroyed.

Consequently, some of the structural members were not able to carry the applied load and collapsed. The bottom part of the columns and ground floor slab sustained heavy damage, where the bottom part of the girders (tension zone) sustained most of the damage. The spalling of concrete exposed the steel reinforcements to high temperatures, which caused a reduction in the strength and yield of the reinforcements. This resulted in the formation of large 
TABLE 2: Large-scale fire tests.

\begin{tabular}{|c|c|c|c|c|c|}
\hline $\begin{array}{l}\text { Author, year, } \\
\text { and ref. no. }\end{array}$ & Descriptions & Methods & Parameters & Limitations & Conclusions \\
\hline $\begin{array}{l}\text { Panedpojaman } \\
\text { et al. (2016) [53] }\end{array}$ & $\begin{array}{l}\text { Precast concrete cantilever beam } \\
\text { connected to precast concrete } \\
\text { middle beam by a welded plate } \\
\text { joint with different fire protection } \\
\text { methods }\end{array}$ & $\begin{array}{l}\text { (i) Load test } \\
\text { (ii) Fire test using } \\
\text { gas burner } \\
\text { (standard fire } \\
\text { curve EN 1991-1- } \\
2 \text { or ASTM E119 } \\
\text { for } 120 \text { min) }\end{array}$ & $\begin{array}{l}\text { (i) Failure } \\
\text { patterns } \\
\text { (ii) Load } \\
\text { resistances } \\
\text { (iii) Load- } \\
\text { deflection } \\
\text { curves } \\
\text { (iv) Load-rebar } \\
\text { strain curves } \\
\text { (v) Load-steel } \\
\text { plate strain } \\
\text { curves }\end{array}$ & $\begin{array}{l}\text { (i) Postfire effect to } \\
\text { the concrete } \\
\text { structure } \\
\text { (ii) Internal } \\
\text { temperature } \\
\text { distribution data } \\
\text { (iii) Moment } \\
\text { capacity, rotational } \\
\text { capacity, the } \\
\text { rotational stiffness, } \\
\text { and the fixity factor }\end{array}$ & $\begin{array}{l}\text { (i) The fire resistance } \\
\text { durations were } 66,113 \text {, } \\
>120 \text { and }>120 \mathrm{~min} \\
\text { for the specimens } \\
\text { without fire } \\
\text { protection, with thin } \\
\text { plaster, with thick } \\
\text { plaster, and with } \\
\text { sealant, respectively } \\
\text { (ii) The beam end } \\
\text { deflection gradually } \\
\text { increased with fire } \\
\text { duration and increased } \\
\text { significantly at failure }\end{array}$ \\
\hline $\begin{array}{l}\text { Teja et al. (2019) } \\
\text { [3] }\end{array}$ & $\begin{array}{l}\text { Precast concrete cantilever beam } \\
\text { connected to precast concrete } \\
\text { column with three different } \\
\text { connections-monolithic, hybrid, } \\
\text { and corbel }\end{array}$ & $\begin{array}{l}\text { (i) Load test } \\
\text { (ii) Fire test using } \\
\text { gas burner } \\
\text { (constant } \\
\text { temperature } \\
400^{\circ} \mathrm{C} \text { for } 60 \mathrm{~min} \text { ) }\end{array}$ & $\begin{array}{l}\text { (i) Load- } \\
\text { displacement } \\
\text { curves } \\
\text { (ii) First crack } \\
\text { (iii) Ultimate } \\
\text { crack } \\
\text { (iv) Toughness }\end{array}$ & $\begin{array}{l}\text { (i) Internal } \\
\text { temperature } \\
\text { distribution data } \\
\text { (ii) Exposure to } \\
\text { standard fire curve } \\
\text { EN 1991-1-2 or } \\
\text { ASTM E119 } \\
\text { (iii) Boundary } \\
\text { condition for top } \\
\text { and bottom column } \\
\text { (iv) Postfire effect to } \\
\text { the concrete } \\
\text { structure } \\
\text { (v) Moment- } \\
\text { rotation- } \\
\text { temperature } \\
\text { characteristics, the } \\
\text { rotational stiffness, } \\
\text { and the fixity factor }\end{array}$ & $\begin{array}{l}\text { Corbel connection } \\
\text { showed better } \\
\text { performance in terms } \\
\text { of toughness } \\
\text { compared to } \\
\text { monolithic and hybrid } \\
\text { connection }\end{array}$ \\
\hline
\end{tabular}

cracks at the bottom of the girders and loss of bond between the concrete and the steel. The girders were not able to carry the applied load and collapsed.

3.1.2. Personal Care Product Factory, Poland [25]. The factory was constructed in 1968 with reinforced concrete columns ( $400 \mathrm{~mm} \times 400 \mathrm{~mm}, \mathrm{C} 16$ concrete grade) fixed to the foundation footings $(18 \mathrm{~m} \times 6 \mathrm{~m}$ column grid), posttensioned roof girders (180 m span, $1.40 \mathrm{~m}$ high, C30 concrete grade, $1500 \mathrm{MPa}$ grade steel, four $12 \varnothing 5 \mathrm{~mm}$ tendons, $\mathrm{T}$ sections of chords with $200 \mathrm{~mm} \times 300 \mathrm{~mm}$ bottom and $300 \mathrm{~mm} \times 200 \mathrm{~mm}$ top), and reinforced concrete thin-walled ribbed roof panels supported on the girders ( $6 \mathrm{~m}$ span, C20 concrete grade, $25 \mathrm{~mm}$ thick, $300 \mathrm{~mm}$ high), as shown in Figure 8 . There was no fire suppression system in the part of the facility where the fire occurred. The information on the method used to connect both components is not available.

The methods adopted in the report are the same as those adopted in the study by Ref. [23], including visual examination and observation, tensile test on prestressing reinforcement, and SEM observation. The damage to the structure is extensive. The marked reduction of the loadbearing capacity rendered the factory unusable. The columns were inclined and curved due to the thermal elongation of roof girders and panels and the horizontal action of the collapsing roof girders. There was cracking on the lower surface of the columns. The temperature increase and the accelerated relaxation of high-strength steel reduced the prestressing force, which in turn increased the deflection and width of the joints in the bottom chords of the girders. The corrosion of the exposed prestressing reinforcement in the damaged anchorage zones and the open joints reduced the load-bearing capacity of the girders. The completely uncovered anchorage zones of the prestressing steel or the cracked and broken concrete cover accelerated the corrosion of the steel elements.

The fire began in the precast concrete frames (compartments $\mathrm{C}$ and $\mathrm{E}$ ), which collapsed several hours after the fire started even though the fire burned the longest in these compartments. Although some of the structural damage to certain parts of the building occurred in the early stages of the fire (less than one hour), the concrete frame hall where 
TABle 3: Computer simulations and analytical model.

\begin{tabular}{|c|c|c|c|c|c|}
\hline $\begin{array}{l}\text { Author, year, } \\
\text { and ref. no. }\end{array}$ & Descriptions & Methods & Parameters & Limitations & Conclusions \\
\hline $\begin{array}{l}\text { Reis et al. } \\
\text { (2009) [54] }\end{array}$ & $\begin{array}{l}\text { Fire damage to precast, } \\
\text { prestressed concrete } \\
\text { double-tee beam in a } \\
\text { parking structure }\end{array}$ & $\begin{array}{l}\text { Analytical model: } \\
\text { (i) Materials engineering } \\
\text { phase (in-place and } \\
\text { laboratory testing) } \\
\text { (ii) Load-testing phase } \\
\text { (verify load-carrying } \\
\text { capacity) }\end{array}$ & $\begin{array}{l}\text { (i) Concrete } \\
\text { spalling } \\
\text { (ii) Aggregate } \\
\text { colour } \\
\text { (iii) Concrete } \\
\text { cracking } \\
\text { (iv) Pulse velocity } \\
\text { (v) Elastic } \\
\text { modulus } \\
\text { (vi) Splitting } \\
\text { tensile strength } \\
\text { (vii) Midspan } \\
\text { deflection-load } \\
\text { curves } \\
\text { (viii) Cracking } \\
\text { moment }\end{array}$ & $\begin{array}{l}\text { Thermal } \\
\text { behaviour of the } \\
\text { beam-to-column } \\
\text { connection at high } \\
\text { temperature }\end{array}$ & $\begin{array}{l}\text { The analytical model } \\
\text { confirmed: } \\
\text { (i) General findings of the } \\
\text { evaluation program } \\
\text { pertinent to the midspan } \\
\text { deflections and the load } \\
\text { testing } \\
\text { (ii) Means of comparing the } \\
\text { deflection response with the } \\
\text { test findings }\end{array}$ \\
\hline
\end{tabular}

(i) Maximum combustion gas temperature

Fire damage to precast

Pessiki and Bayreuther (2013) [55] concrete double-tee beams, pocketed spandrels, walls, and inverted-tee girders
Computational fluid dynamics program for a series of vehicle fires and the resulting fire loads (ii) Maximum

prestressing steel behaviour of the temperature

(iii) Gas temperature time histories

(iv) Temperature

distributions beam-to-column (i) Geometry of structure have a significant effect on the movement of combustion gases in the structure connection at high (ii) Fires cause greater increases in prestressing steel temperatures and reduced the steel strength

(i) The extent of fire in time and space, and the (i) Fire Dynamics Simulator ver. 5 for Personal care product thermal condition in

factory, Poland (2012), building containing precast column and precast posttensioned girder (ii) Lusas for thermal condition in structural elements and mechanical analysis of the entire structural (i) Thermal condition in building

(ii) Temperature distribution in

structural elements
Thermal behaviour of the beam-to-column connection at high temperature temperatures reached the structure resisted the fire very effectively

(ii) The computational fluid dynamics and global mechanical analyses give only a rough estimation of the real fire and structure behaviour due to shortage of precise information and numerical data on the fire the fire originated did not collapse until several hours later. The collapse of the central part of the building and the pushing out of the outer parts caused significant damage to the posttensioned roof girders, reinforced concrete slabs, and columns. The foundation footings remained intact.

3.1.3. Production Hall, Novi Sad, Serbia [26]. The building was constructed using precast concrete columns and precast façade beams with concrete grade C35/45. The information on the size of the members and the method used to connect the members is not available. However, the figure given by the researcher shows that the end of the precast façade beam is discontinuous and is seated on top of the precast column, which caused the façade beam to rotate and decline. Detailed information on the fire intensity is not available. Figure 9 shows the general view of the building after the fire.
The methods used in the report include visual inspection of the physical effects, dimension measurement, concrete coring, tensile test of the reinforcement, and geodetic survey. The major interior parts with installations, roof coverings, and facade cladding, as well as the complete roof-bearing structure, were destroyed during the fire. The precast columns and precast facade beams suffered severe damage. A detailed visual inspection revealed the following defects and damages: (1) insufficient protective concrete layer, (2) rough concrete surface, (3) spalled, fallen, or burnt concrete protection layer, (4) change in the colour of the concrete surface, (5) crumbling and burnt concrete protective layer with the aggregate grains showing a colour change, (6) crumbly longitudinal column edges, (7) net-like fissures on the surface of the elements, (8) horizontal cracks along the stirrups, (9) horizontal cracks due to flexion of the columns, (10) vertical cracks and gaps along the column edges (along 
TABLE 4: Fire resistance test on the precast connection elements.

\begin{tabular}{|c|c|c|c|c|c|}
\hline $\begin{array}{l}\text { Author, year, } \\
\text { and ref. no. }\end{array}$ & Descriptions & Methods & Parameters & Limitations & Conclusions \\
\hline $\begin{array}{l}\text { Zhang et al. } \\
\text { (2018) [56] }\end{array}$ & $\begin{array}{l}\text { Tensile behaviour of } \\
\text { half-grouted sleeve } \\
\text { connection at elevated } \\
\text { temperatures }\end{array}$ & $\begin{array}{l}\text { (i) Grouted } \\
\text { specimens and } \\
\text { single rebars } \\
\text { under static } \\
\text { tension at } \\
\text { different } \\
\text { temperatures } \\
\text { (ii) Furnace test } \\
\text { (iii) Tensile test }\end{array}$ & $\begin{array}{l}\text { (i) Grout compression strength } \\
\text { (ii) Grout vertical expansion } \\
\text { ratio } \\
\text { (iii) Failure modes } \\
\text { (iv) Ultimate tensile force and } \\
\text { yield tensile force } \\
\text { (v) Ultimate elongation } \\
\text { (vi) Yield elongation } \\
\text { (vii) Ductility factor } \\
\text { (viii) Elastic modulus }\end{array}$ & $\begin{array}{l}\text { (i) Thermal } \\
\text { effect when } \\
\text { embedded in } \\
\text { concrete with } \\
\text { concrete spalling } \\
\text { (ii) Exposure to } \\
\text { higher } \\
\text { temperature } \\
>600^{\circ} \mathrm{C} \\
\text { (iii) Full-scale } \\
\text { beam with half- } \\
\text { grouted sleeve } \\
\text { connection } \\
\text { exposed to fire }\end{array}$ & $\begin{array}{l}\text { (i) At normal } \\
\text { temperature, half } \\
\text { grout sleeves exhibited } \\
\text { two types of } \\
\text { failure-rebar fracture } \\
\text { and rebar pull-out } \\
\text { (ii) At elevated } \\
\text { temperature, the } \\
\text { failure mode and } \\
\text { rebar breakpoint } \\
\text { location were changed } \\
\text { at } 600^{\circ} \mathrm{C}\end{array}$ \\
\hline $\begin{array}{l}\text { Zhang et al. } \\
\text { (2019) [57] }\end{array}$ & $\begin{array}{l}\text { Mechanical behaviour } \\
\text { of postfire half-grouted } \\
\text { sleeve connection } \\
\text { covered by concrete }\end{array}$ & $\begin{array}{l}\text { (i) Single rebar, } \\
\text { grouted rebar } \\
\text { with cover, and } \\
\text { grouted rebar } \\
\text { without concrete } \\
\text { cover } \\
\text { (ii) Furnace test } \\
\text { (iii) Tensile test }\end{array}$ & $\begin{array}{l}\text { (i) The properties-strength, } \\
\text { elongation, ductility, and } \\
\text { elastic modulus } \\
\text { (ii) The failure } \\
\text { mechanism-elongation, } \\
\text { bonding slip, influence of } \\
\text { concrete cover, and bonding } \\
\text { behaviour }\end{array}$ & $\begin{array}{l}\text { (i) Exposure to } \\
\text { higher } \\
\text { temperature } \\
>600^{\circ} \mathrm{C} \\
\text { (ii) Full-scale } \\
\text { beam with half- } \\
\text { grouted sleeve } \\
\text { connection } \\
\text { exposed to fire }\end{array}$ & $\begin{array}{l}\text { Postfire tensile } \\
\text { properties of the half- } \\
\text { grouted sleeve } \\
\text { connection were } \\
\text { obviously affected by } \\
\text { the peak temperature } \\
\text { and the concrete cover }\end{array}$ \\
\hline $\begin{array}{l}\text { Panedpojaman } \\
\text { et al. (2016) [53] }\end{array}$ & $\begin{array}{l}\text { Fire protection of the } \\
\text { welded plate } \\
\text { joint-without any fire } \\
\text { protection, with } \\
\text { mortar plaster, and } \\
\text { with intumescent } \\
\text { sealant of } 1 \mathrm{~cm} \\
\text { thickness }\end{array}$ & $\begin{array}{l}\text { (i) Load test } \\
\text { (ii) Fire test using } \\
\text { gas burner } \\
\text { (standard fire } \\
\text { curve EN 1991-1- } \\
2 \text { or ASTM E119 } \\
\text { for } 120 \text { min) }\end{array}$ & $\begin{array}{l}\text { (i) Deflection } \\
\text { (ii) Failure mode } \\
\text { (iii) Plate failure } \\
\text { (iv) Spalling } \\
\text { (v) Cracking }\end{array}$ & $\begin{array}{l}\text { (i) Postfire effect } \\
\text { to the concrete } \\
\text { structure } \\
\text { (ii) Internal } \\
\text { temperature } \\
\text { distribution data }\end{array}$ & $\begin{array}{l}\text { Thick plaster was the } \\
\text { best alternative for } \\
\text { preventing joint } \\
\text { damage. To reduce the } \\
\text { cost, flexible sealant is } \\
\text { recommended }\end{array}$ \\
\hline
\end{tabular}

the main reinforcement), (11) broken, spalled, and fallen concrete along the edge of the columns, (12) impaired adhesion between the concrete and reinforcement, (13) exposed reinforcement, and (14) local mechanical damage of the concrete in places where interior elements were fixed. Two possible repair solutions were analysed, namely, repair of the precast concrete columns and removal of the existing precast concrete columns and replacing them with new ones.

3.2. Large-Scale Fire Tests. Most large-scale fire tests were conducted on monolithic concrete beam-to-column connection [21, 22, 28, 65-67]. Only a few investigations were carried out on precast concrete beam-to-column connections, as shown in Table $2[3,53]$. However, the large-scale fire tests on the monolithic concrete beam-to-column connection were beneficial as further references and guidelines. Many studies performed large-scale fire tests on steel and composite structures due to the greater fire risk of steel and composite structures. These studies investigated the different sources of heat, including natural fire, large-scale furnace, small-scale furnace, gas burner, and flexible ceramic pad (FCP) [68]. Most large-scale fire tests on monolithic concrete beam-to-column were conducted on cantilever beam setup with a furnace or gas burner placed at the joint area $[3,22,53,66,67]$. However, in the method adopted by Raouffard and Nishiyama [28], the full-length beam is supported by columns at the ends.

Panedpojaman et al. [53] conducted a large-scale fire test on precast concrete beam-to-column connection to investigate the moment capacity and fire protection performance of the welded plate joint for precast members exposed to high temperature, as shown in Figure 10. In this case, a similar welded connection can be designated to the precast beam-to-column connection. The researchers investigated four types of joints: (1) joints without fire protection, (2) joints protected with $15 \mathrm{~mm}$ thick mortar plaster, (2) joints protected with $40 \mathrm{~mm}$ thick mortar plaster, and (4) joints protected with $19 \mathrm{~mm}$ thick intumescent sealant. The specimens were exposed to fire from below for up to $120 \mathrm{~min}$. Due to the limitation of laboratory testing, this fire was specified as a parametric fire following the specifications in EN 1991-1-2, which is a realistic range for office or house fire. This fire curve is slightly less severe than the standard fire curve in EN 1991-1-2 or ASTM E119. The parameters investigated in the test include failure patterns, load 
TABLE 5: Assessments and rehabilitations of fire-damaged concrete structure.

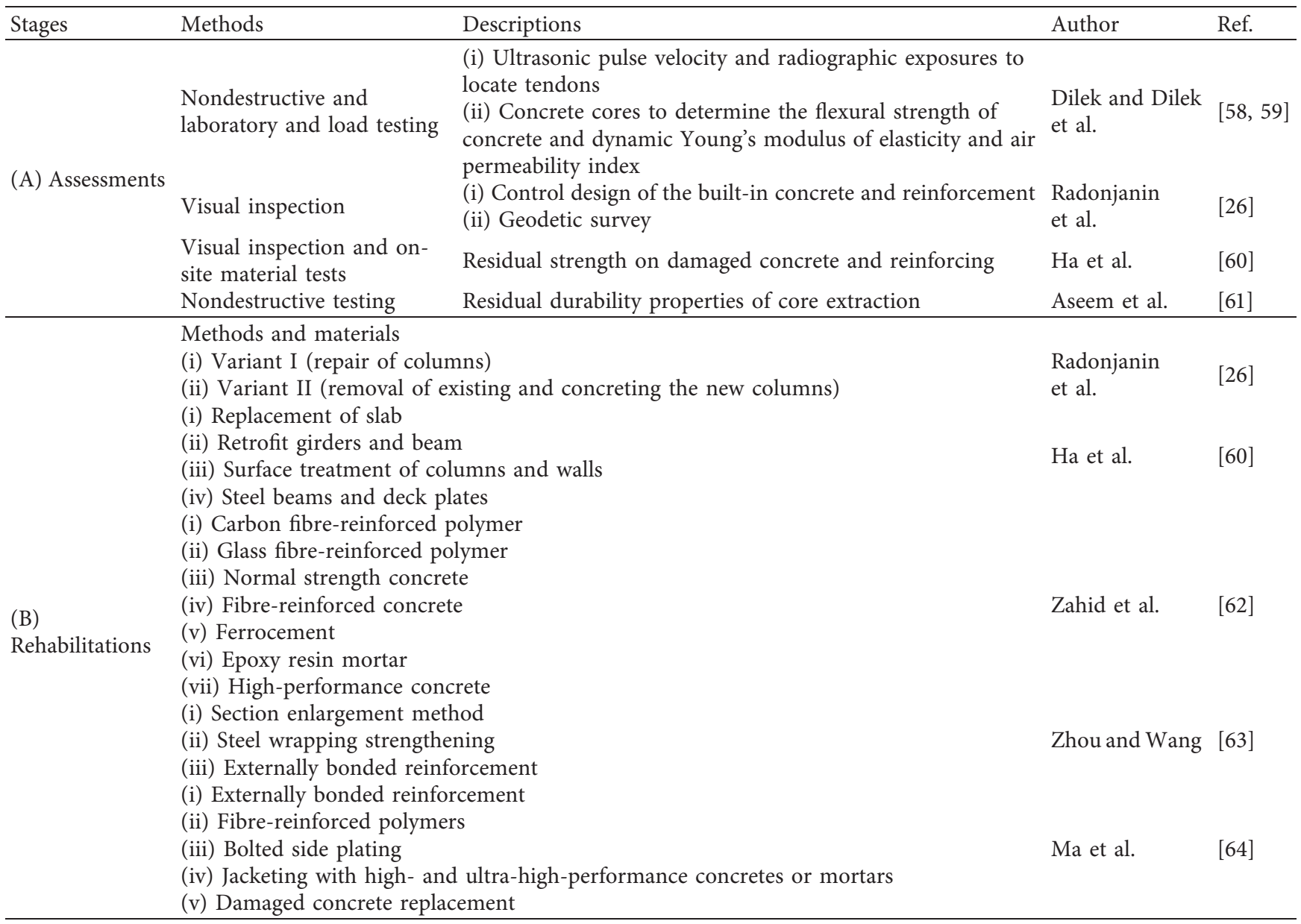

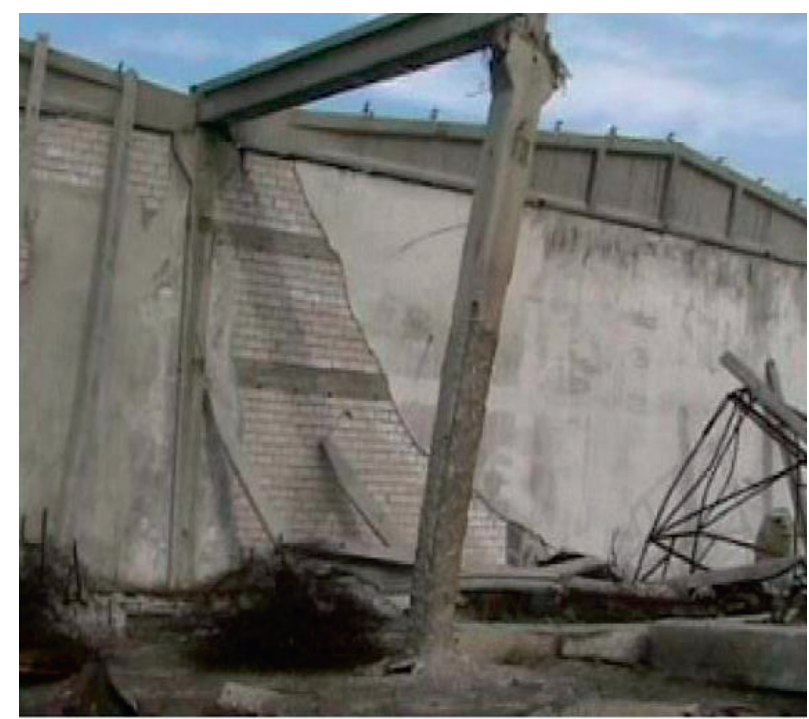

Figure 7: General view of the plant after the fire [23]. 


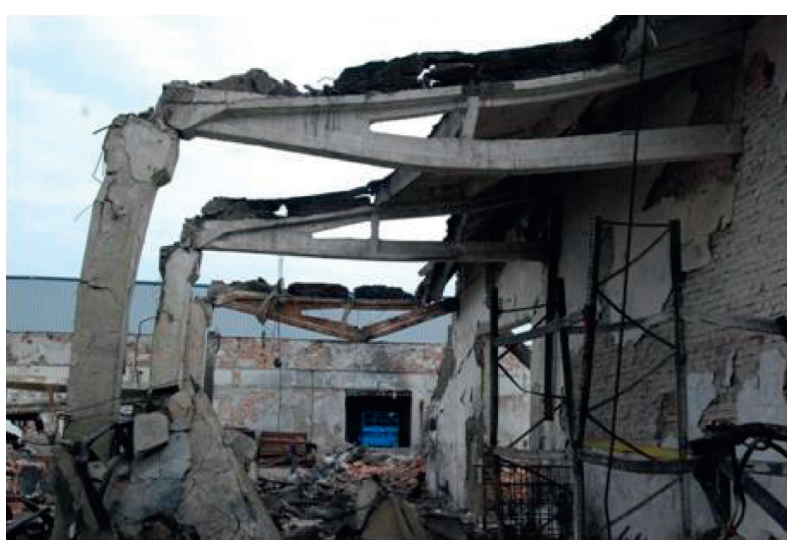

(a)

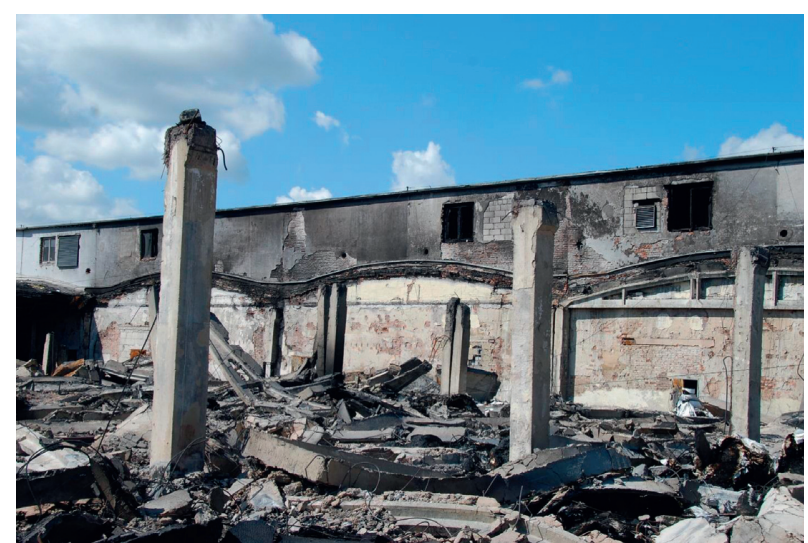

(b)

Figure 8: Factory condition after the fire: (a) inclined and curved columns and deformed roof girders and (b) collapsed roof [25].

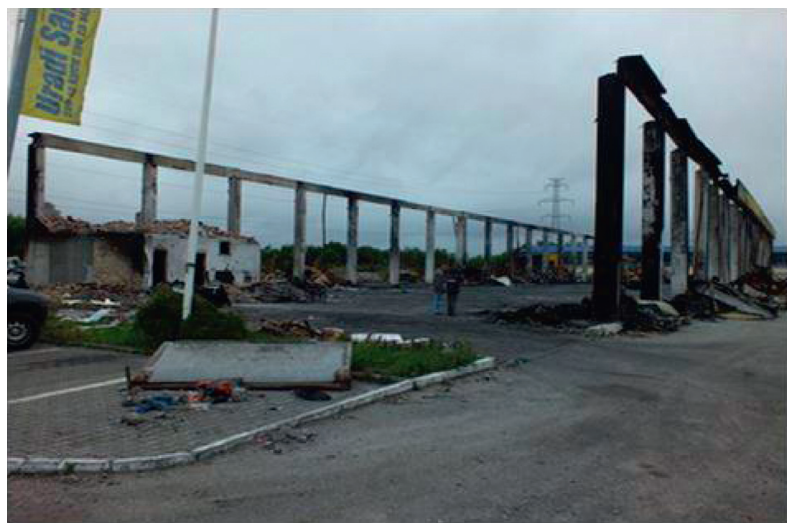

(a)

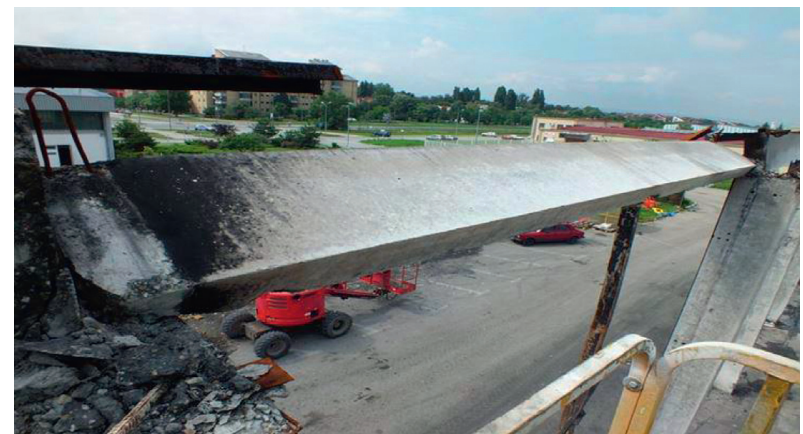

(b)

Figure 9: General view of the building after the fire: (a) appearance of the objects after the fire and clearing of the ground and (b) beam rotation (tends to decline) [26].

resistances, load-deflection curves, load-rebar strain curves, and load-steel plate strain curves.

During the fire test, the higher deflection at the beam end caused a separation of the cantilever beam, joint, and main beam. Thermal damage and expansion caused the fire-resistant plaster to crack and break off. The plate swelled, and the upper edge of the plate split. The mechanical degradation of the plate reduced the moment capacity of the joint. The fire resistance duration of the specimens without fire protection, with thin plaster, with thick plaster, and with sealant is 66 , 113 , >120, and $>120 \mathrm{~min}$, respectively. The fire-resistant sealant has good flexibility and remains intact when exposed to fire, which allows it to cover and protect the joint. Based on these findings, thick plaster seems to be the best option in preventing joint damage. Nonetheless, the application of thick plaster may not be feasible due to its high cost. Thus, the use of flexible sealant as a fire protection material is recommended for welded plate joints.

Teja et al. [3] used the cantilever beam method identical to that used by Refs. [22, 67] to investigate the performance of precast hybrid and corbel connections exposed to high temperatures shown in Figure 11. The specimens were exposed to a constant fire temperature of $400^{\circ} \mathrm{C}$ provided by a gas burner for 60 minutes. The hybrid connection consists of a cleat angle with two stiffeners on both edges and a small stiffener in the middle. The beam reinforcement was linked to the cleat angle using arc welding in the vertical face and then cast in a mould. Another plate was welded at the centre of the main reinforcement of the column and cast. After curing, both specimens were joined using a bolted connection. The corbel connection was formed by a precast concrete beam supported on a precast concrete column corbel. The gaps between the rebar and concrete were filled with grout. A cleat angle with stiffeners on either side was provided towards the top of the beam. The cleat angle was simultaneously anchored vertically into the beam and horizontally into the column that restrains the upwardlifting of the beam. Grout was applied in the vertical interface to increase the rotational flexural stiffness and flexural strength capacity of the connections. The parameters investigated in the test include load-displacement curve, first crack, ultimate crack, and toughness. 

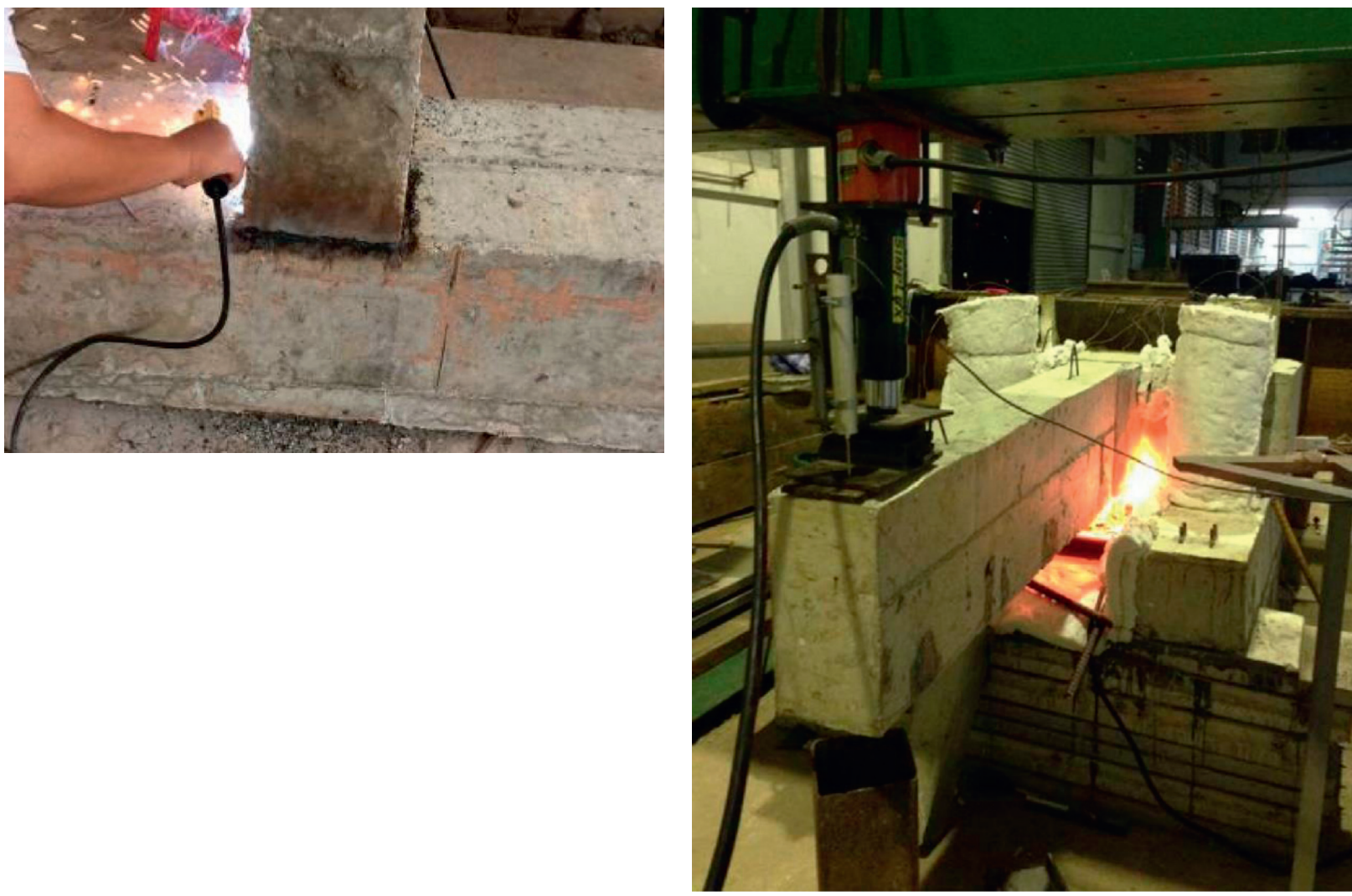

(a)

(b)

Figure 10: (a) Electric welding of a welded plate joint and (b) experimental setup [53].

The result of the fire test showed that the specimen with corbel connection has the best performance in terms of joint toughness. The first crack at the ultimate load for corbel connection $(53 \%)$ is less than those for monolithic (55\%) and hybrid (58\%) connections. However, the displacement at the first crack for corbel (56\%) is higher than those for monolithic (28\%) and hybrid (37\%) connections.

\subsection{Computer Simulations and Analytical Models.} Computer simulations and analytical models are used to validate experimental findings and improve engineering recommendations. Many studies have been conducted on steel beam-to-column connection to determine the moment-rotation-temperature relationships [34-37], as described in Section 2. Among the finite element simulation programs used to make the simulations are ABAQUS, VULCAN, ADAPTIC, DIANA, and ANSYS. However, no comprehensive study has been carried out on the precast concrete beam-to-column connection under high-temperature conditions, as shown in Table 3. Most studies focused on precast prestressed slabs $[54,55,69]$ and fire dynamics simulation of precast building [25].

Reis and Mata [54] and Pessiki [55] developed an analytical model for fire-damaged double tees in a parking structure to evaluate the fire damage sustained by precast prestressed concrete members of the parking structure. The analytical model used by Reis and Mata [54] includes the materials engineering phase (in-place and laboratory testing) and load-testing phase (verify load-carrying capacity). The parameters involved in the analytical model include concrete spalling, aggregate colour, concrete cracking, pulse velocity, elastic modulus, splitting tensile strength, midspan deflection-load curves, and cracking moment. The analytical models confirmed the findings of the experimental program on midspan deflection, load testing, the significant effect of the structure's geometry, and the strength of prestressing steel.

Reference [55] used a computational fluid dynamics (CFD) computer program to perform an analysis. Heat flux histories were used as the input to determine the temperature rise in the prestressing strand of the double-tee floor members. The increased prestressing steel temperatures were used to estimate the reductions in steel strength. The parameters in the analytical model are maximum combustion gas temperature, maximum prestressing steel temperature, gas-temperature time history, and temperature distribution. The result showed that the geometry of a structure has a significant effect on the movement of combustion gases in the structure. Fires have significantly increased prestressing steel temperature and reduced steel strength. 


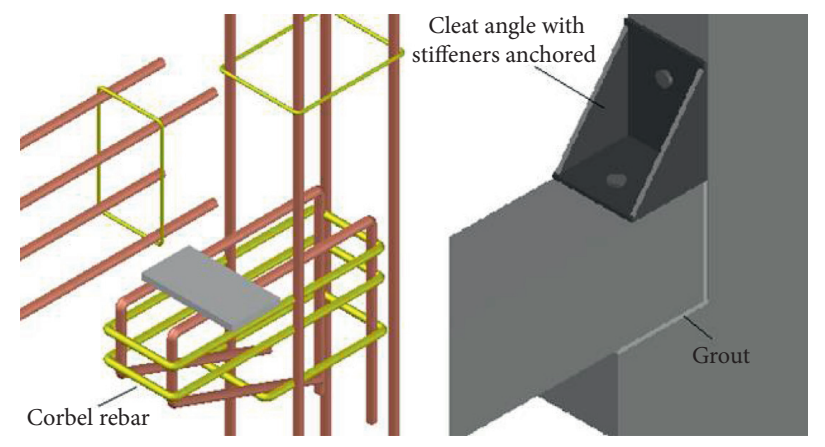

(a)

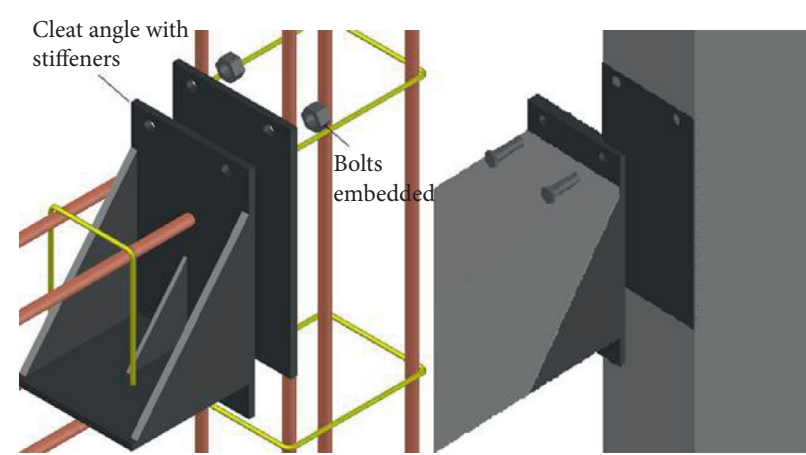

(b)

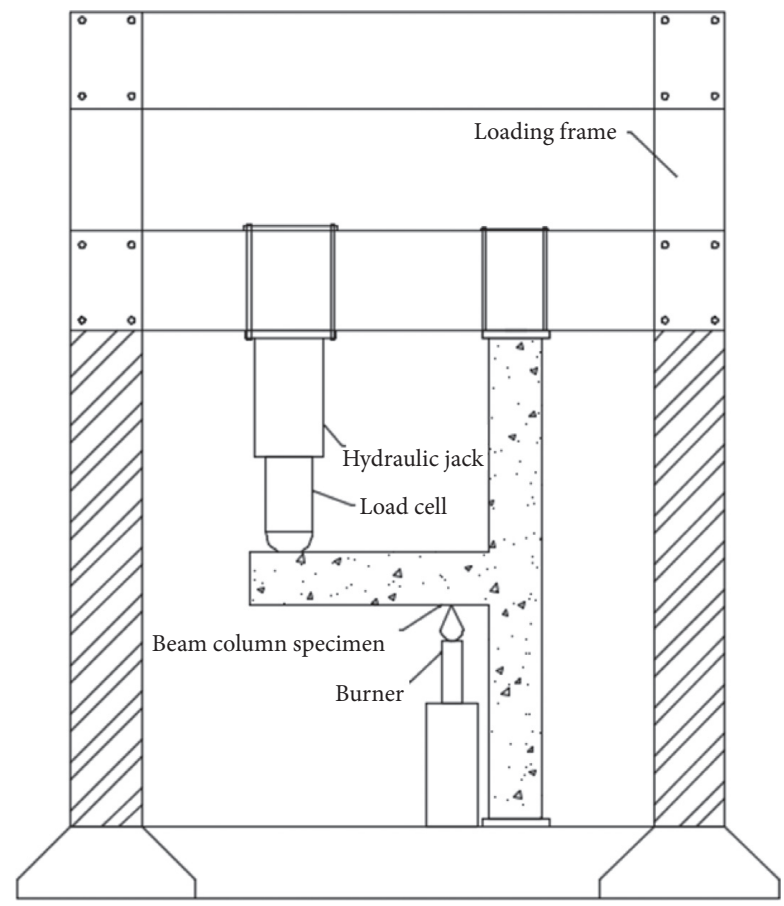

(c)

FIGURE 11: (a) Corbel connection, (b) hybrid connection, and (c) experimental setup [3].

The dynamics simulation study of the precast building using the CFD computer program (Fire Dynamics Simulator ver. 5) by Ref. [25] showed the extent of fire in time and space and the temperatures reached and that the structure was able to resist the fire very effectively. The CFD and global mechanical analyses gave a rough estimation of the real fire and structure behaviour due to the lack of accurate information and numerical data on the fire.

A comparison with previous studies on computer simulations of monolithic concrete beam-to-column connection shows that the computer simulations performed by Kodur and Shakya [69] on a precast prestressed concrete hollow-core slab at a high temperature are congruent with the predicted temperature and the test data. The hollow-core slabs were able to resist the fire for 95 minutes because of the influence of the load, concrete cover thickness, and core size. However, the failure of a precast prestressed concrete hollow-core slab in the fire is due primarily to the degradation of moment capacity or increased deflection, as well as the limiting temperature on the unexposed surface. These parameters are influenced by the temperature rise in the slabs and the corresponding loss of strength and modulus of the prestressing strand.

Annerel and Taerwe [29] modelled internal and external thermal restraints to investigate the behaviour of concrete beam-column connections exposed to ISO 834 fire. Results showed that the vertical cracks in the concrete element caused by the internal thermal restraint did not extend to the bottom surface of the heated beam. External thermal restraint was observed with the gradual development of plastic hinges and increasing shear force that occurred well before the fire resistance stated in EN 1992-1-2 is attained. Thermal deformation may cause cracking in the building elements that are not directly exposed to the fire. Additional reinforcement, concrete cover, and insulation can be provided to strengthen the structure.

Kodur and Agrawal [70] assessed the residual capacity of fire exposed reinforced concrete beams. The researchers 
examined the material properties of the reinforcing steel and concrete under three conditions: (1) structural response in ambient condition, (2) thermomechanical response during fire exposure, and (3) postfire residual response after the beams have cooled down. The assessment took into account the load level, specific fire scenarios, boundary conditions, and plastic deformation of the beams. In contrast with the simplified cross-sectional analysis, taking into account the temperature-dependent strain hardening properties of steel reinforcement and the tension stiffening properties of concrete gives a more realistic prediction of the residual capacity. Large irrecoverable plastic deformation may remain in the fire exposed reinforced concrete beams, and higher residual deformations reduced the postfire residual capacity of the reinforced concrete beams. The reinforced concrete beams analysed in this study retained about 60 to $70 \%$ of their ultimate room temperature capacity for different parametric fire exposure scenarios with a distinct cooling phase.

Eid et al. [66] performed a theoretical analysis of the behaviour of reinforced concrete beam-column connections exposed to fire by considering the effect of reinforcement ratio, the number of stirrups on reinforced concrete connection, and the duration of the fire. The experimental program also determined the heat distribution in reinforced concrete beam-to-column connections by measuring the temperature at different points. In contrast to the experimental results, finite element analysis is a more efficient method for predicting the structural behaviour of reinforced concrete beam-to-column connection. The theoretical results are in good agreement with the experimental results.

3.4. Fire Resistance Test on the Precast Connection Elements. The fire resistance of connection elements is a critical factor in the design of precast connections. The connection elements in precast structures comprise bearing pads, grout, bolts, and welds. Generally, the connection elements transfer compressive stress through direct contact or the insertion of a material [71]. The direct contact method is rarely used due to the low-tension strength and fragile behaviour of the concrete. Researchers have investigated the performance of half-grouted sleeve and welded connection at elevated temperatures $[53,56,57]$, as shown in Table 4. However, thus far, no extensive study has been carried out on the fire behaviour of bearing pads, bolts, and welds [71-75].

Half-grouted sleeve connections (HGSC) are often used to join rebars in precast concrete structures. Zhang et al. [56] and Zhang et al. [57] performed a furnace test and tensile test to investigate the mechanical behaviour of postfire halfgrouted sleeve connection covered with concrete at elevated temperatures. They found that the tensile properties of halfgrouted sleeve connections are directly affected by temperature. The compressive strength of the grouts and the bonding length decreased at $600^{\circ} \mathrm{C}$. The half grout sleeves exhibited two types of failure: (1) rebar fracture and (2) rebar pull-out due to bonding failure. The failure mode and location of rebar breakpoint may change at elevated temperatures.
The strength of a welded connection is dependent on the quality of metal-to-metal contact. Welded connections must be protected from fire. Panedpojaman et al. [53] investigated the fire protection of the welded plate joint. The load test and fire test in this research were carried out using a gas burner (standard fire curve EN 1991-1-2 or ASTM E119 for $120 \mathrm{~min}$ ). The researchers found that the flexibility of sealant fire protection makes it suitable for covering and protecting welded connections. Even though thick plaster is the best method for preventing joint damage, its utilisation is not cost-effective. Therefore, the use of flexible sealant is recommended for protecting welded plate joints from fire.

Bearing pads are essential in precast concrete connections to provide a uniform distribution of contact stress over the bearing areas and allow relative movement between the precast concrete elements to prevent cracking at the connection area. El Debs et al. [71] stated that alternative materials fabricated using styrene-butadiene latex-modified cement mortar, polymeric fibres, and lightweight aggregate (vermiculite) could be used as bearing pad due to their excellent compression strength and low elasticity modulus. According to El Debs et al. [72], the optimum amount of fibre should be used to enhance the capacity of the bearing pad to accommodate surface irregularities. The performance of glass fibres subjected to concentrated load is superior to that of polyvinyl alcohol fibres. Poor positioning of the bearing pad over the reinforced concrete corbel could cause premature failure of the structure [74].

The advantages of bolt connections are their reliability, convenience, and rapid assembly. Bolt connections are often installed together with steel plates and rubber layers [75]. Guo et al. [76] asserted that high-strength bolt connections play a critical role in the initial structure stiffness and have considerable influence on the dynamic response of a structure because it is the primary lateral resistance component. Bolt connections must be perfect for reducing structural acceleration response. According to Zhong et al. [75], precast specimens with bolt connections have almost the same ultimate bearing capacity and failure mode as monolithic cast-in-place specimens.

\subsection{Assessment and Rehabilitation of Fire-Damaged Precast} Concrete. Many building structures that have experienced severe fire have been repaired and put back into service [20]. However, postfire structures that are heavily damaged and have collapsed cannot be put back into service [23]. Their load-bearing capacity has been considerably reduced, making them unusable. A thorough assessment showed that fire-damaged precast concrete structures could be repaired or strengthened and therefore do not have to be demolished and reconstructed. Researchers have assessed and even rehabilitated fire-damaged precast concretes [26, 58, 59]. They focused on the precast prestressed double-tee concrete of a parking structure and the precast components (beam and column) of a factory building. Currently, there is no comprehensive research on the rehabilitation of fire-damaged precast concrete beam-to-column connections. A previous in-depth discussion on this subject focused on the 
assessment and rehabilitation of fire-damaged precast and monolithic concrete structures, as shown in Table 5.

Investigators have carried out a comprehensive investigation of the fire damage sustained by precast concrete beam-to-column connections and found that, unlike the external columns, the internal columns were severely damaged [23]. Similarly, the bottom part of the beams and girders suffered heavy damage. The concrete layer spalled and exposed the reinforcement to a high temperature $[23,26]$, which caused the reinforcements to lose their strength and yield. The colour of concrete changed to pink or red $[23,26]$. Some of the structural members were no longer able to carry the applied load and collapsed [25]. There are vertical and horizontal cracks on the structures [26].

Dilek [58] and Dilek et al. [59] conducted nondestructive testing (NDT) and load and laboratory testing to assess the fire damage sustained by the precast prestressed concrete members of a parking structure. Ultrasonic pulse velocity and radiographic exposures were used to locate the tendons before removing the cores. Concrete cores from the samples were examined to determine the flexural strength, dynamic Young's modulus of elasticity, and air permeability index of the concrete. Radonjanin et al. [26] performed a visual inspection to assess the fire damage sustained by the precast concrete of a factory. The researchers also developed a control design of the built-in concrete and reinforcement, conducted a geodetic survey, and made a conclusion on the state of the structure.

As a comparison, the assessment of fire-damaged monolithic concrete was used. Ha et al. [60] made a visual inspection of the damaged structures, and this was followed by a finite element analysis and on-site material tests of the concrete core cylinders and rebar coupons to determine the degree of neutralisation in the remaining structure. The specimens of damaged concrete and reinforcing bars were tested to determine their residual strengths. Aseem et al. [61] assessed the residual durability properties of the reinforced concrete structural column and shear walls using an NDT and determined their residual mechanical properties using core extraction tests. The results of microstructural and thermal analyses were used to develop a framework for estimating the exposure temperatures of the various structural units.

Radonjanin et al. [26] proposed two possible methods for rehabilitating fire-damaged precast concretes, variant I (repair of columns) and variant II (removal of existing columns and concreting new columns). Both methods predicted that the severely damaged façade beams have to be removed. Ha et al. [60] recommended replacing the slabs with new ones and retrofitting the girders and beams. The surface of the columns and walls could be treated and do not require structural retrofitting. Given the tight construction schedule and the complexity of the rehabilitation work, the researchers recommended for the steel beams and deck plates to function as temporary slabs during the rehabilitation period and as permanent supplementary slabs after the rehabilitation work is completed.

Zahid et al. [62] recommended using materials such as carbon fibre-reinforced polymer, glass fibre-reinforced polymer, normal strength concrete, fibre-reinforced concrete, ferrocement, epoxy resin mortar, and highperformance concrete for repairing a structure. The material selected for repair work must be compatible with the substrate or base material to ensure an effective repair. Zhou and Wang [63] used section enlargement, steel wrapping strengthening, and externally bonded reinforcement methods to repair fire-damaged reinforced concrete columns. The section enlargement method was particularly effective in improving the structural bearing capacity, stiffness, and stability of the compressed members. The steel jacketing prevented concrete spalling while increasing the ultimate load capacity. According to $\mathrm{Ma}$ et al. [64], the suitable methods for repairing fire-damaged concrete structures are externally bonded reinforcement, near surface-mounted fibre-reinforced polymers, bolted side plating, jacketing with high-performance and ultrahigh-performance concretes or mortars, and replacement of the damaged concrete.

3.6. Conclusion of the Previous Studies. The following conclusions are drawn based on the summary of the studies presented in Tables 1-5. In the case study of a real fire, the researchers were unable to determine the thermal behaviour of the beam-to-column connection at high temperatures, the temperature during the fire, the residual compressive strength of heavily damaged concrete, and the solution for rehabilitation. In the large-scale fire tests, the researchers were unable to determine the postfire effect on the concrete structure, the moment-rotation-temperature characteristics, rotational stiffness, and fixity factor in the semirigid connections.

Concerning the computer simulations and analytical models, the researchers were unable to determine the thermal behaviour of the beam-to-column connection at high temperatures. The researchers were unable to use the result of the fire resistance test on the precast connection elements to explain the thermal effect of HGSC by considering the concrete spalling and exposure to temperatures $>600^{\circ} \mathrm{C}$. The researchers were also unable to determine the fire performance of bearing pads and bolts at elevated temperatures. Regarding the assessment and rehabilitation of fire-damaged precast concrete, no comprehensive research has been carried out on the precast concrete beam-to-column connections.

\section{Issues}

4.1. The Effect of Fire on Semirigid Concrete Beam-to-Column Connections. Unlike the effect of fire on steel structures, the fire effect on semirigid concrete beam-to-column connections has not been extensively explained. There is an urgent need to understand the moment-rotation-temperature characteristics of semirigid concrete beam-to-column connections at elevated temperatures. Currently, the focus to ensure fire protection of mechanical connection is only given in the design stage. However, designers are very concerned with the thermal behaviour of the semirigid 
concrete beam-to-column connections under severe fire conditions. The continuously increasing rotation at the joint, diminishing moment capacity, small cross section, and material deterioration reduced the capability of connections to preserve a structure's integrity, strength, energy dissipation, stiffness, and ductility.

As mentioned earlier, this review paper is concerned with whether the effects of fire on rigid connections and semirigid connections are comparable. A rigid connection is a frame system that can resist moment and is constructed using a monolithic concrete cast in place with the continuity of top reinforcement in a ductile connection at the support, whereas, in semirigid connection, joint flexibility is taken into account. The method for constructing semirigid connections is different from that used for rigid connections. Hidden concrete corbels have precast elements such as bearing pads, dowel bars, and grout between the joints. The dry, semidry, and wet methods can be used to construct semirigid connections and take into consideration the effect of fire on these elements. Two of the most common types of semirigid connections (welded plate connection and billet connection) are constructed using separate elements.

Depending on the flexural stiffness of the connection, the maximum elastic bending moment of semirigid connection occurs at the support or midspan (provided that the semirigid end connections have the same flexural stiffness capacity) between the pinned and rigid support beam and permits a reduction in the beam material. The optimum connection allows just enough end rotation to balance between the end moment and midspan moment. Exposure to severe fire will cause changes in the bending moment diagram.

\subsection{The Effect of Fire on Pinned Concrete Beam-to-Column} Connections. There is currently no detailed description of the effect of fire on pinned concrete beam-to-column connections. Previous studies focused on the effect of fire on the bottom surface of precast members such as hollow-core slab [69, 77-79], prestressed girder [80], and prestressed beam [81-83] that have simple connections. Although concrete exhibits good performance under compression, its performance under tension is not satisfactory. Concrete must be able to resist the tensile stress caused by fire and the bending force from applied loads that can cause cracking and, ultimately, failure.

Determination of the effect of fire on pinned connections must take into consideration two factors, the installation of a precast beam with a pinned joint condition without a moment at the support and the simply supported precast roof beam with no slab. Both connections have a small stiffness that can be classified as pinned. However, the literature review showed that the interlocking effects of infill grouting and shear friction could cause the development of small moments of resistance, which rapidly disappear during service and make the connection "pinned."

The high temperature during a fire may cause midspan deflection and overturn precast beams, as have been observed in real fire incidents $[23,25,26]$. This reaction allows for rotation at the end of the beam. It is critical to understand the effect of midspan rotation, beam overturning, and beam end rotation on beam support and precast elements such as bearing pad, dowel bar, and the grout between the joints. The concrete at the edge of the corbel and the top of the column may spall and expose the steel reinforcements to high temperatures, which consequently reduce the strength of the reinforcements and prevent the pinned connection from transferring the shear and axial force.

\subsection{The Effect of Fire on Precast Connection Classification.} The classification of precast beam connections depends on the value of the beam's moment of resistance and relative pin-beam end rotation in the moment-rotation curve. A severe fire can reduce the material strength and cross section of a structure. These changes affect the values of modulus of elasticity and moment of inertia of the structure, which in turn reduce the moment capacity, rotational capacity, rotational stiffness, and fixity factor of semirigid connections.

It is possible to reduce the moment-rotation curve from close to that in Plot 1 (rigid connection with no rotation) and approach the curve in Plot 2 (pinned connection with no moment resistance) (refer to Figure 1). In this case, semirigid is an intermediary behaviour between fully rigid and perfect pinned connections that partially transmits the stress and has a certain degree of rotational stiffness. When this happens, the primary concern is the overall structural building analysis. The connection, whether it is designed as a rigid, semirigid, and pinned connection, requires a different shear force and bending moment diagram during the structural design. Structures with insufficient reinforced design may fail.

4.4. Fire Test on Semirigid and Pinned Connections. There is a degree of uncertainty in the fire tests used for semirigid and pinned concrete beam-to-column connections. Most largescale fire tests for monolithic concrete beam-to-column connection use a cantilever beam setup and a furnace or gas burner at the joint area. The tests adopted the concept of an ideal beam-to-column connection under no lateral thermally induced thrust and no moment redistribution influence by removing the midsection of the reinforced concrete beam and turning it into two separate reinforced concrete cantilever beams [22]. This raises the question of whether similar fire test methods can be used for semirigid and pinned connections.

In Figure 1, the moment at the semirigid connection is smaller than the moment at the rigid connection, while the pinned connection produces minimal moment resistance. For this reason, the cantilever beam method may be suitable for semirigid connections with a certain degree of moment reduction. The simply supported method is more suitable for pinned connections because of the significant rotation at the beam end. Previous studies have used a similar method on hollow-core slabs [69, 77-79], prestressed girders [80], and prestressed beams [81-83] with simple connections. Fire tests must consider the essential criteria of the beam-to-column connections, including 
connection stiffness, transfer of force between members, restoring force characteristics, and equivalent or superior serviceability, durability, and fire safety.

Fire tests on semirigid and pinned connections must consider the effect of the reduced scale of specimens. A review of the literature shows that the specimens for rigid connections are one-half to one-third smaller than the actual structure. Also, the issues surrounding the tests, including the different types of precast beam-to-column connection (corbel, hidden-corbel, bolted endplate), effects of loading (static or cyclic), the inclusion of reinforcement, and differences in concrete properties, must be taken into account.

Another concern with fire tests is the residual strength methods used to determine the effect of fire on semirigid and pinned concrete beam-to-column connections. Previous studies applied a static or cyclic load to the beam-to-column connection specimens and exposed the specimens to a fire in a large-scale furnace. The custom-made large-scale furnace used in beam-to-column connection tests is different from the standard large-scale furnace and not readily available. Thus, there is a need to develop alternative testing methods. In the past, the residual strength methods were employed to investigate the postfire behaviour of concrete at elevated temperatures. Standard size concrete cube specimens were prepared and burned in the furnace without a load. Similarly, the specimens for beam-to-column connection were burned in a normal large-scale furnace and separately tested under standard static or cyclic loading.

\subsection{Rehabilitation of Fire-Damaged Semirigid and Pinned} Connections. At present, there is no in-depth investigation and description of rehabilitation of fire-damaged semirigid and pinned concrete beam-to-column connections. In this regard, three critical factors must be taken into consideration: (1) rehabilitation of fire-damaged precast concrete structure, (2) rehabilitation of precast concrete elements, and (3) performance of the postrehabilitated precast connection. The fire-damaged precast structure will be repaired, strengthened, partially demolished, or completely demolished and reconstructed.

Table 5 presents a summary of the assessment and rehabilitation of fire-damaged concrete structures. Most studies focused on the connections and joints between precast structures. The semirigid and pinned connections are connected by vertical and horizontal components, while the precast elements are protruding reinforcements, bearing pads, grouts, bolts, and welds. The methods for rehabilitating normal structures are different from those for rehabilitating precast structures.

The precast elements of precast structures damaged in a fire must be rehabilitated. Engineers must understand the possible failure modes and the critical aspect of the joints because different materials react differently during a fire depending on the exposure temperature. The rehabilitation of fire-damaged elements has to be done using suitable alternative materials and methods, and this includes the design, installation, and monitoring process. The rehabilitated precast beam-to-column connections must be assessed to determine the performance under static or cyclic loading. After completing the rehabilitation process, engineers must make sure that the load-bearing capacity is adequate for future use.

\section{Challenges}

Precast pinned connections are seldom used in regions with high seismic activity because they cannot carry lateral and seismic loads in high-rise buildings. However, they are often used in low-rise buildings. The continuity between the beam and the column in the connection area can improve the performance behaviour of the pinned joint as it acts as a rigid or semirigid connection. Previously, most fire tests were conducted on rigid concrete connections under cyclic loading. Fire tests and computer simulations of semirigid and pinned precast concrete connections under cyclic loading are a challenging task as they have to take into account exposure temperature, type of connection, construction method, and material properties.

Design for Deconstruction (DfD) is an increasingly popular concept in civil engineering because the components of DfD buildings can be reused as a second life at the end of the service life of the first building. Similarly, Prefabricated Prefinished Volumetric Construction (PPVC) is a new, advanced modular construction technology that facilitates higher productivity in the construction industry. Although the design takes fire protection into account (concrete cover and drywall partition), the effect of fire on the connection between the beam and the column is still unknown. There is a need to perform large-scale fire tests and computer simulations on the actual specimens, which take into account the event of a fire during installation and service.

The most recent technologies in beam-to-column connection are prefabricated bolted beam-to-column connection, steel beam-to-column connection, beam-to-column welded connection, dry-type high-strength bolt connection, and exterior reinforced concrete column and steel connection. Another type of connection used in the construction industry is the composite connection, where the steel beam is cast with the concrete. Tests should be carried out to understand the effect of fire on the new connection technologies, especially steel structures, to ensure that the entire structure is fire resistant. These tests should aim to provide a better understanding of the interaction between the bending moment and axial load in the heated internal joint after the loss of the column.

With the availability of the different types of beam-tocolumn connections, the design of the systems, including connections, beams, and columns, should be standardised to ensure a reliable precast construction system. The use of standard components can reduce manufacturing cost, production error, or erection error. Standardisation can also reduce inconsistencies and improve quality and manufacturing efficiency. 


\section{Conclusions}

The global precast concrete market is forecast to grow in the future. The precast industry is currently undergoing rapid expansion because of its high production efficiency, better product quality, and low labour intensity. The design of a structure must meet the fire safety requirement for precast buildings to keep pace with the rapid progress. Design engineers must consider accidental actions, including the effects of fire. Beam-to-column connections are the most important connections in precast skeletal frames. Exposure to an extreme fire produces destructive forces within the beam-to-column connections that cause structural deterioration, as observed in the recent fire accidents throughout the globe. The following conclusions are drawn from the review of precast concrete beam-to-column connections under fire conditions:

(1) Precast concrete beam-to-column connections are classified (rigid, semirigid, and pinned) using the moment-rotation relationship beam-line method and connection classification system.

(2) The moment-rotation-temperature relationships for precast concrete beam-to-column connection are influenced by the effects of fire on the reinforced concrete structure, including deflection, cracking, spalling, loss of stiffness and strength, and reinforcement strength loss.

(3) The change in the properties of concrete structure as a result of exposure to high temperatures affects the moment capacity, rotational capacity, rotational stiffness, and fixity factor of the semirigid connections.

(4) The case studies of fire effect on precast structures showed that the beam-to-column connections sustained severe damage. Some of the main structural members were not able to carry the applied load and collapsed. Their load-bearing capacity was considerably compromised, making them unusable. These studies explored the possibility of rehabilitating the structures by repairing or demolishing and rebuilding the main structures.

(5) Several studies investigated the effect of fire on precast concrete beam-to-column connections. The different sources of heat used in large-scale fire tests are natural fire, large-scale furnace, small-scale furnace, gas burner, and FCP. The tests were conducted on the cantilever and simply supported beams. Among the investigated parameters are the first crack, displacement, toughness of the joints, and fire protection.

(6) The fire resistance of connection elements (bearing pad, grout, bolt, and weld) is a critical parameter in the design of precast connections. The tensile properties of half-grouted sleeve connections were directly affected by temperature. The quality of metal-to-metal contact determines the strength of the welded connections. Alternative materials fabricated from styrene-butadiene latex-modified cement mortar, polymeric fibres, and lightweight aggregates (vermiculite) can be used as bearing pads due to the excellent compression strength and low elasticity modulus of the materials. High-strength bolt connections play a critical role in the initial structural stiffness and have a strong influence on the dynamic response of a structure.

(7) The main issues faced by the researchers are the lack of research conducted on the effect of fire on semirigid and pinned concrete beam-to-column connections, the effect of fire on the precast connection classification, the level of uncertainty in fire tests, and the insufficient understanding of the method for rehabilitating fire-damaged connections.

(8) The challenges faced by current researchers are the inadequate procedure for performing fire tests and computer simulations of semirigid and pinned precast concrete connections under cyclic loading. New fire tests and computer simulations must be developed to complement the concepts of DfD and PPVC. There is also a need to standardise the design of connection systems to achieve a feasible precast construction system.

\section{Data Availability}

No data were used to support the findings of the study.

\section{Conflicts of Interest}

The authors declare that they have no known conflicts of financial interest or personal relationships that could have appeared to influence the work reported in this paper.

\section{Acknowledgments}

The authors acknowledge the financial support from Universiti Kebangsaan Malaysia through Research University Grant (grant no. GUP-2018-027) and laboratory facilities provided by the Department of Civil Engineering, Faculty of Engineering and Built Environment, Universiti Kebangsaan Malaysia.

\section{References}

[1] I. Hollý and I. Harvan, "Connections in precast concrete elements," Key Engineering Materials, vol. 691, pp. 376-387, 2016.

[2] K. W. Ding and X. Zhang, "Literature review of precast concrete frame structures in civil engineering," Advanced Materials Research, vol. 568, pp. 3-6, 2012.

[3] C. S. Teja, T. S. Moturu, G. Yaswanth Kumar, H. A. Khan, G. Y. Kumar, and H. A. Khan, "Effect of fire on prefabricated concrete beam column 'Connections," International Journal of Recent Technology and Engineering, vol. 8, no. 2, pp. 1433-1436, 2019.

[4] Y. Rui, "The review of problems in precast construction activities," Journal of Social Science Research, vol. 2, pp. 173-176, 2018. 
[5] A. B. Abd Rahman and W. Omar, "Issues and challenges in the implementation of industrialised building systems in Malaysia," in Proceedings of the 6th Asia-Pacific Structural Engineering and Construction Conference (APSEC 2006), pp. C-45-C-53, Kuala Lumpur, Malaysia, September 2006.

[6] V. Turai and A. Waghmare, "A study of cost comparison of precast concrete vs. Cast-in-Place," International Journal of Advanced Engineering Research Application, vol. 2, no. 2, pp. 112-122, 2016.

[7] W. He, Z. Yinqi, G. Weijun, and D. Student, "A review of precast concrete building development in different countries," in Proceedings of 128th The IIER International Conference, pp. 8-11, Auckland, New Zealand, October 2017.

[8] M. P. GULHANE and S. R. S. R. Bhuskade, "Review on analysis of precast concrete structure," International Journal of Advance Engineering and Research Development, vol. 4, no. 04, pp. 742-747, 2017.

[9] K. Qian, S.-L. Liang, F. Fu, and Q. Fang, "Progressive collapse resistance of precast concrete beam-column sub-assemblages with high-performance dry connections," Engineering Structures, vol. 198, p. 109552, 2019.

[10] H. H. Ghayeb, H. Abdul Razak, and N. H. Ramli Sulong, "Seismic performance of innovative hybrid precast reinforced concrete beam-to-column connections," Engineering Structures, vol. 202, p. 109886, 2020.

[11] K. S. Elliott, Precast Concrete Structures, CRC Press, Taylor \& Francis Group, Boca Raton, FL, USA, 2nd edition, 2017.

[12] Building and Construction Authority (BCA), Connections for Advanced Precast Concrete System, Building and Construction Authority (BCA), Singapore, Singapore, 2018.

[13] R. Mokhtar, Z. Ibrahim, M. Z. Jumaat, Z. A. Hamid, A. Hazim, and A. Rahim, "Behaviour of semi-rigid precast beam-to-column connection determined using static and reversible load tests," Measurement, vol. 164, p. 108007, 2020.

[14] M. M. S. Lacerda, T. J. da Silva, G. M. S. Alva, and M. C. V. de Lima, "Influence of the vertical grouting in the interface between corbel and beam in beam-to-column connections of precast concrete structures-an experimental analysis," Engineering Structures, vol. 172, no. May, pp. 201-213, 2018.

[15] FIB Bulettin 43, Structural Connections for Precast Concrete Buildings, International Federation for Structural Concrete, Lausanne, Switzerland, 2008.

[16] T. Fatema, "Study on connection between precast concrete beam and cast-in-situ column in prefabricated building frames," Journal of Engineering and Applied Sciences, vol. 1, no. 1, pp. 33-38, 2006.

[17] H. Gorgun, "Semi-rigid behaviour of connections in precast concrete structures," Ph. D Thesis, University of Nottingham, Nottingham, UK, 1997.

[18] M. E. Kartal, H. B. Başağa, A. Bayraktar, and M. Muvafik, "Effects of semi-rigid connection on structural responses," Electronic Journal of Structural Engineering, vol. 10, pp. 22-35, 2010.

[19] S. Mohammed and A. Inamdar, "Joints and Connections in Precast Concrete Buildings," International Journal of Science and Research (IJSR), vol. 7, no. 6, p. 2017, 2019.

[20] A. H. Buchanan and A. K. Abu, Structural Design for Fire Safety, Excelic Press LLC, Lewes, DE, USA, Second edition, 2017.

[21] M. M. Raouffard and M. Nishiyama, "Residual load bearing capacity of reinforced concrete frames after fire," Journal of Advanced Concrete Technology, vol. 14, no. 10, p. 625, 2016.
[22] M. M. Raouffard and M. Nishiyama, "Fire response of exterior reinforced concrete beam-column subassemblages," Fire Safety Journal, vol. 91, pp. 498-505, 2017.

[23] M. M. Kose, H. Temiz, and H. Binici, "Effects of fire on precast members: a case study," Engineering Failure Analysis, vol. 13, no. 8, pp. 1191-1201, 2006.

[24] J. Gales, L. A. Bisby, and M. Gillie, "Unbonded post tensioned concrete in fire: a review of data from furnace tests and real fires," Fire Safety Journal, vol. 46, no. 4, p. 151, 2011.

[25] R. Wróblewski, J. Gierczak, P. Smardz, and A. Kmita, "Fire and collapse modelling of a precast concrete hall," Structure and Infrastructure Engineering, vol. 12, no. 6, pp. 714-729, 2016.

[26] V. Radonjanin, M. Malešev, I. Lukić, S. Šupić, and S. Vukoslavčević, "The assessment and repair of the precast RC structure exposed to fire," Istrazivanja I Projektovanja Za Privredu, vol. 14, no. 1, p. 1, 2016.

[27] M. M. Raouffard, "Structural behavior of reinforced concrete elements and subassemblies under fire conditions," $\mathrm{Ph} . \mathrm{D}$ Thesis), Kyoto University, Kyoto, Japan, 2018.

[28] M. M. Raouffard and M. Nishiyama, "Fire resistance of reinforced concrete frames subjected to service load: Part 1. experimental study," Journal of Advanced Concrete Technology, vol. 13, no. 12, pp. 554-563, 2015.

[29] E. Annerel and L. Taerwe, "Robustness of a typical beamcolumn concrete structure exposed to fire," IABSE Symposium Report, vol. 100, no. 4, pp. 210-216, 2013.

[30] S. Deeny, T. Stratford, R. P. Dhakal, P. J. Moss, and A. H. Buchanan, "Spalling of Concrete: Implications for Structural Performance in fire," in Futures in Mechanics of Structures and Materials-Proceedings of the 20th Australasian Conference on the Mechanics of Structures and Materials, ACMSM20, Toowoomba, Queensland, December 2008.

[31] Z. Huang, I. N. W. Burgess, and R. J. Plank, "Behaviour of reinforced concrete structures in fire," in Proceedings of the 4th International Workshop on Structures in Fire, p. 561, Aveiro, Portugal, January 2006.

[32] İ. B. Topçu and C. Karakurt, "Properties of reinforced concrete steel rebars exposed to high temperatures," Research Letters in Materials Science, vol. 2008, Article ID 814137, 4 pages, 2008.

[33] N. Hashim and J. Agarwal, "Rotational stiffness of precast beam-column connection using finite element method," IOP Conference Series: Earth and Environmental Science, vol. 140, p. 012128, 2018.

[34] V.-L. Tran, "Moment-rotation-temperature model of semirigid cruciform flush endplate connection in fire," Fire Safety Journal, vol. 114, p. 102992, 2020.

[35] K. S. Al-Jabri, I. W. Burgess, T. Lennon, and R. J. Plank, "Moment-rotation-temperature curves for semi-rigid joints," Journal of Constructional Steel Research, vol. 61, no. 3, pp. 281-303, 2005.

[36] K. S. Al-Jabri, J. B. Davison, and I. W. Burgess, "Performance of beam-to-column joints in fire-A review," Fire Safety Journal, vol. 43, no. 1, p. 50, 2008.

[37] R. Rahnavard and R. J. Thomas, "Numerical evaluation of the effects of fire on steel connections; Part 2: model results," Case Studies in Thermal Engineering, vol. 13, p. 100361, 2019.

[38] B. Georgali and P. E. Tsakiridis, "Microstructure of firedamaged concrete. A case study," Cement and Concrete Composites, vol. 27, no. 2, p. 255, 2005.

[39] A. M. Gil, B. Fernandes, F. L. Bolina, and B. F. Tutikian, "Experimental analysis of the spalling phenomenon in precast reinforced concrete columns exposed to high temperatures," 
Revista IBRACON de Estruturas e Materiais, vol. 11, no. 4, p. 856, 2018.

[40] C. Maraveas and A. A. Vrakas, "Design of concrete tunnel linings for fire safety," Structural Engineering International: Journal of the International Association for Bridge and Structural Engineering (IABSE), vol. 24, no. 3, pp. 319-329, 2014.

[41] G. A. Khoury, "Effect of fire on concrete and concrete structures," Progress in Structural Engineering and Materials, vol. 2, no. 4, pp. 429-447, 2000.

[42] M. Hedayati, M. Sofi, P. A. Mendis, and T. Ngo, "A comprehensive review of spalling and fire performance of concrete members," Electronic Journal of Structural Engineering, vol. 15, no. 1, pp. 8-34, 2015.

[43] M. B. Dwaikat and V. K. R. Kodur, "Fire induced spalling in high strength concrete beams," Fire Technology, vol. 46, no. 1, p. 251, 2010.

[44] N. N. M. Pauzi, M. Jamil, R. Hamid, A. Z. Abdin, and M. F. M. Zain, "The effects of using cathode ray tube (CRT) glass as coarse aggregates in high-strength concrete subjected to high temperature," Journal of Material Cycles and Waste Management, vol. 21, no. 6, pp. 1414-1425, 2019.

[45] F. Omar, S. A. Osman, and A. Mutalib, "Nano-silica as the go material on heat resistant tunnel lining," IOP Conference Series: Materials Science and Engineering, vol. 342, no. 1, Article ID 012071, 2018.

[46] H. Alhawat, R. Hamid, S. Bahroom, and M. H. Mussa, "A review on large-scale fire testing of concrete tunnel lining," Journal of Engineering and Applied Sciences, vol. 14, no. 9, pp. 2891-2897, 2019.

[47] R. K. Ibrahim, R. Hamid, and M. R. Taha, "Fire resistance of high-volume fly ash mortars with nanosilica addition," Construction and Building Materials, vol. 36, p. 779, 2012.

[48] R. K. Ibrahim, R. Hamid, and M. R. Taha, "Strength and microstructure of mortar containing nanosilica at high temperature," ACI Materials Journal, vol. 111, no. 2, 2014.

[49] M. H. Mussa, A. A. Mutalib, R. Hamid, and S. N. Raman, "Dynamic properties of high volume fly ash nanosilica (HVFANS) concrete subjected to combined effect of high strain rate and temperature," Latin American Journal of Solids and Structures, vol. 15, no. 1, 2018.

[50] S. Iffat and B. Bose, "A review on concrete structures in fire," International Journal of Civil, Environmental, Structural, Construction and Architectural Engineering, vol. 10, no. 2, 2016.

[51] I. Fletcher, S. Welch, J. Torero, R. Carvel, and A. Usmani, "Behaviour of concrete structures in fire," Thermal Science, vol. 11, no. 2, pp. 37-52, 2007.

[52] M. Ada, B. Sevim, N. Yüzer, and Y. Ayvaz, Assessment of Damages on a RC Building After a Big Fire, Advanced Concrete Construction Inc, Sheridan, CO, USA, 2018.

[53] P. Panedpojaman, P. Jina, and S. Limkatanyu, "Moment capacity and fire protection of the welded plate joint for precast members," Archives of Civil and Mechanical Engineering, vol. 16, no. 4, pp. 753-766, 2016.

[54] E. M. Reis and L. A. Mata, "An analytical model for estimating load-test deflections in fire-damaged precast, prestressed concrete members," PCI Journal, vol. 54, no. 3, pp. 129-142, 2009.

[55] S. Pessiki, "Analytical investigation of vehicle fires in precast concrete parking structures," PCI Journal, vol. 53, no. 3, pp. 111-123, 2013.

[56] W. Zhang, X. Deng, J. Zhang, and W. Yi, "Tensile behavior of half grouted sleeve connection at elevated temperatures,"
Construction and Building Materials, vol. 176, pp. 259-270, 2018.

[57] W. Zhang, C. He, J. Zhang, W. Yi, and X. Deng, "Mechanical behavior of post-fire half-grouted sleeve connection covered by concrete," Construction and Building Materials, vol. 201, pp. 218-231, 2019.

[58] U. Dilek, "Evaluation of fire damage to a precast concrete structure nondestructive, laboratory, and load testing," Journal of Performance of Constructed Facilities, vol. 19, no. 1, pp. 42-48, 2005.

[59] U. Dilek, T. Caldwell, E. F. Sharpe Jr., and M. L. Leming, "Fire damage assessment, pre-stressed concrete double-tees at parking deck," in Proceedings of the Congress (ASCE American Society of Civil Engineers, no. 919, pp. 247-258, Honolulu, HI, USA, March 2003.

[60] T. Ha, J. Ko, S. Lee, S. Kim, J. Jung, and D.-J. Kim, “A case study on the rehabilitation of a fire-damaged structure," Applied Sciences, vol. 6, no. 5, p. 126, 2016.

[61] A. Aseem, W. Latif Baloch, R. A. Khushnood, and A. Mushtaq, "Structural health assessment of fire damaged building using non-destructive testing and micro-graphical forensic analysis: a case study," Case Studies in Construction Materials, vol. 11, Article ID e00258, 2019.

[62] M. M. Zahid, B. A. Bakar, F. Nazri, M. Ahmad, and K. Muhamad, "Review of repair materials for fire-damaged reinforced concrete structures," IOP Conference Series: Materials Science and Engineering, vol. 318, Article ID 012023, 2018.

[63] J. Zhou and L. Wang, "Repair of fire-damaged reinforced concrete members with axial load: a review," Sustainability (Switzerland), vol. 11, no. 4, 2019.

[64] W. Ma, C. Yin, J. Zhou, and L. Wang, "Repair of fire-damaged reinforced concrete flexural members: a review," Sustainability, vol. 11, no. 19, p. 5199, 2019.

[65] L. Bisby, J. Gales, and C. Maluk, "A contemporary review of large-scale non-standard structural fire testing," Fire Science Reviews, vol. 2, no. 1, p. 1, 2013.

[66] F. Eid, K. Heiza, and M. Elmahroky, "Behavior and analysis of reinforced self-compacted concrete beam column connection subjected to fire," American Journal of Science, Engineering and Technology, vol. 2, no. 4, pp. 132-140, 2017.

[67] K. Heiza, M. Taha, and M. Soliman, "Performance of reinforced concrete beam column connections exposed to fire under cyclic loading," The International Conference on Civil and Architecture Engineering, vol. 11, no. 11, p. 1, 2016.

[68] N. A. M. Radzi, R. Hamid, and A. A. Mutalib, "A review of methods, issues and challenges of small-scale fire testing of tunnel lining concrete," Journal of Applied Sciences, vol. 16, no. 7, pp. 293-301, 2016.

[69] V. K. R. Kodur and A. M. Shakya, "Modeling the response of precast, prestressed concrete hollow-core slabs exposed to fire," PCI Journal, vol. 59, no. 3, pp. 78-94, 2014.

[70] V. K. R. Kodur and A. Agrawal, "An approach for evaluating residual capacity of reinforced concrete beams exposed to fire," Engineering Structures, vol. 110, pp. 293-306, 2016.

[71] M. K. El Debs, A. da Silva Ramos Barboza, and A. M. Miotto, "Development of material to be used for bearing pad in precast concrete connections," Structural Concrete, vol. 4, no. 4, pp. 185-193, 2003.

[72] M. K. El Debs, L. C. Montedor, and J. B. de Hanai, "Compression tests of cement-composite bearing pads for precast concrete connections," Cement and Concrete Composites, vol. 28, no. 7, pp. 621-629, 2006. 
[73] D. Guan, Z. Guo, C. Jiang, S. Yang, and H. Yang, "Experimental evaluation of precast concrete beam-column connections with high-strength steel rebars," KSCE Journal of Civil Engineering, vol. 23, no. 1, pp. 238-250, 2019.

[74] R. C. Neupane, L. Eddy, and K. Nagai, "Investigation on strengthening approaches adopted for poorly detailed RC corbels," Fibers, vol. 5, no. 2, pp. 1-15, 2017.

[75] Y. Zhong, F. Xiong, J. Chen, A. Deng, W. Chen, and X. Zhu, "Experimental study on a novel dry connection for a precast concrete beam-to-column joint," Sustainability, vol. 11, no. 17, p. 4543, 2019.

[76] W. Guo, Z. Zhai, Y. Cui, Z. Yu, and X. Wu, "Seismic performance assessment of low-rise precast wall panel structure with bolt connections," Engineering Structures, vol. 181, pp. 562-578, 2019.

[77] A. M. Shakya and V. K. R. Kodur, "Response of precast prestressed concrete hollowcore slabs under fire conditions," Engineering Structures, vol. 87, pp. 126-138, 2015.

[78] A. Van Acker, "Shear resistance of prestressed hollow core floors exposed to fire," Structural Concrete, vol. 4, no. 2, pp. 65-74, 2003.

[79] J. V. Aguado, A. Espinos, A. Hospitaler, J. Ortega, and M. L. Romero, "Influence of reinforcement arrangement in flexural fire behavior of hollow core slabs," Fire Safety Journal, vol. 53, pp. 72-84, 2012.

[80] M. Garlock, I. Paya-Zaforteza, V. Kodur, and L. Gu, "Fire hazard in bridges: review, assessment and repair strategies," Engineering Structures, vol. 35, p. 89, 2012.

[81] N. Kalaba, P. Bamonte, and R. Felicetti, "Prestressed members under natural fires: a preliminary study on the residual behaviour," in 2015: Proceedings of the International Conference, pp. 15-16, Dubrovnik, Croatia, October 2015.

[82] S. Baba, S. Michikoshi, S. Sakamoto, and T. Hirashima, "Fire performance of precast prestressed concrete beam with openings," in Structures in Fire - Proceedings of the Sixth International Conference, SiF'10, pp. 157-164, East Lansing, MI, USA, June 2010.

[83] N. M. Okasha and S. Pessiki, "Restraint mechanisms in precast concrete double-tee floor systems subjected to fire," PCI Journal, vol. 58, no. 3, pp. 95-110, 2013. 